\title{
Why has there been a fall in child labor and an increase in school attendance in Mexico?
}

https://onlinelibrary.wiley.com/share/author/VQI4JQBNWIDXMBAMIAYV?target=10.1111/dpr.12 $\underline{611}$

\author{
Jorge Valero \\ Facultad de Economía, Universidad Autónoma de Nuevo León \\ jorge.valerogl@uanl.edu.mx \\ Magali Valero ${ }^{1}$ \\ University of Michigan at Dearborn \\ mvalero@umich.edu
}

This version: March 2021

\begin{abstract}
Understanding the factors affecting child labor and school attendance are primordial to developing policies aimed at improving the lives of children. Policies are needed as poor households can sub-invest in human capital. Factors have individually shown to affect child labor and school attendance, but we question which factors cause the strongest effects by considering them simultaneously. We evaluate which factors have led to the decrease in child labor and the increase in school attendance of children aged 12-14 in Mexico. We consider income, the education of the head-of-household, monetary government transfers, access to public health institutions, remittances and demographic characteristics, as possible sources of the changes. We use a variant of the Oaxaca-Blinder decomposition (Fairlie, 2005), which allows the decomposition in the case the variables to be explained are dichotomous. The change in child labor and school attendance over time can then be decomposed into an explained and an unexplained portion, with each factor contributing a specific amount to the explained portion of the difference. The most important factor that led to the fall child labor and the increase in school attendance was the improvement in the human capital of parents, measured as years of education. The increase in government assistance and greater access to social health insurance also play an important role. Public policies aimed at increasing school attendance and those aimed at reducing child labor should consider the improvement of education as a major goal.
\end{abstract}

\section{Keywords: Schooling, Child Labor, Mexico.}

This is the pre-peer reviewed version of the following article: Why has there been a fall in child labor and an increase in school attendance in Mexico? Forthcoming in Development Policy Revie, which has been published in final form at DOI: $10.1111 / \mathrm{dpr} .12611$. This article may be used for non-commercial purposes in accordance with Wiley Terms and Conditions for Use of Self-Archived Versions.

\footnotetext{
${ }^{1}$ Corresponding Author.
} 


\section{Introduction}

The opportunity of a child to attend school instead of work is an essential topic of sustainable development. Given that children have not fully reached their physical and mental development, they may not yet be able to assess the consequences of working and not attending school, consequences which are important for their future. There are multiple policies aimed at reducing child labor and increasing school attendance. It is important to identify the factors that have led to changes in child labor and school attendance so that appropriate public policies can be implemented; because without government intervention and/or without social norms poor households could sub-invest in human capital and child care (Becker and Murphy, 1988).

This study evaluates the factors that explain the decrease in child labor and the increase in school attendance of children aged 12-14 in Mexico, between the years 2000 and 2010. We analyze how changes in household income per capita, the education of the head of household, access to public health institutions, governmental monetary support, income from remittances, and demographic changes in the household have contributed to the change in child labor and school attendance. Current literature shows many of these factors individually affect school attendance and/or child labor. Our focus is to jointly evaluate them to understand their relative importance in the changes to child labor and to school attendance in Mexico.

We study both child labor and school attendance because the child has a time constraint that includes time to attend school and time to work outside the home so the decisions of whether to send a child to work and/or to school are made simultaneously. The factors that influence whether the child works and/or attends school may be the same, or they may have similar substitution and income effects (Grootaert and Kanbur, 1995, p. 14). Child labor and school attendance need not change one to one as children also have leisure time. For instance, Ravallion 
and Wodon (2000) find a subsidy increases school attendance time by more than it reduces work time in rural Bangladesh, as children can also reduce their leisure time. It is also possible that children can both work and attend school, and further, that working is what makes it possible for children to attend school (Patrinos and Psacharopoulos, 1997, p. 398). Working could also increase the cost of schooling, for instance Psacharopoulos (1997) finds that working children have about two years less of schooling than non-working children of the same age.

We pay special attention to the role of income and education as possible sources of changes in child labor and school attendance. Carneiro and Heckman (2002, 2003) and Chevalier et al. (2013) highlight long-term factors such as permanent household income and the home environment as important determinants of schooling, and distinguish them from current income of the home. Education of the head of the household could also be positively associated with the education of the child, and we distinguish it from the current income of the household.

Mexico faces a significant poverty problem and important efforts have been made in the country to increase school attendance. Among them, a pioneer program that fights poverty and promotes children's education, the Program Oportunidades - Progresa, which was the first transfer program conditional on children attending school. In addition, Mexico is a large remittance recipient and such remittances are an additional source of income that could affect child labor and school attendance. Another important factor is the access to public health institutions. In 2004 such institutions expanded greatly given the creation of the "Seguro Popular" ("Popular Insurance") aimed at providing medical attention to the population in the informal sector, which is a sector where child labor is usually "hidden" 2 .

\footnotetext{
${ }^{2}$ In Mexico, access to health care within public institutions is provided through employment in the formal sector. Starting in 2004 there was an expansion in health services through the "Seguro Popular" which is intended for the population that is not covered by the formal sector of the economy.
} 
We use the available data of the Population censuses of 2000 and 2010, which include more than 460,000 children between the ages of 12 and 14 both for the year 2000 as well as for the year 2010. The large sample allows distinguishing the relative effects of the different factors on child labor and school attendance. We also distinguish between rural and urban sectors, between children aged 12, 13 or 14 and between boys and girls. Given that income inequality is significant in Mexico, we also subdivide Mexican states according to their incidence of poverty.

To decompose the causes of changes in child labor and school attendance between 2000 and 2010, we use the methodology of decomposition of Blinder-Oaxaca, specifically the Fairlie (2005) technique which allows the decomposition for the case in which the variables to be explained are dichotomous. There are many policies aimed at reducing child labor and increasing school attendance, our focus is to jointly evaluate the importance of each of them in order to compare their effectiveness.

We find that the most important factor affecting both child labor and school attendance is the improvement in the human capital of parents, measured as years of education of the head of the household. Between 2000 and 2010 the years of education of the household head increased by $19 \%$ in the urban and by $37 \%$ in the rural households in the sample. We also find that the most important factors reducing child labor are also the ones most important in increasing school attendance. Our results suggest that public policy aimed at reducing child labor and increasing school attendance will have a stronger impact if it is focused on improving education of heads of household and improving access of workers to public health care institutions.

In the next section, we discuss the factors that affect child labor and school attendance, in the context of the current literature. Section 3 discusses the data used in our analysis. Section 4 studies the relationship between per capita income, child labor and school attendance, using kernel 
regressions. In Section 5, we discuss the methodology of decomposition that will be used. Section 6 presents our main results showing the contribution of each factor to the decrease in child labor and to the increase in school attendance. In section 7, we conduct some robustness tests. Finally, the last section concludes.

\section{Factors affecting child labor and school attendance}

\section{Income}

In economic models, the most important factor that influences child labor is income (Becker, 1967; Baland and Robinson, 2000; and Basu and Van, 1998). The premise is that when income is low households are not able to transfer future resources to the present to devote children's time for school. Edmonds (2006) and Edmonds and Schady (2012) verify that child labor is a facet of poverty. In a study of Vietnam, Edmonds $(2005,2008)$ finds that higher income per capita is associated with less child labor and more school attendance. De Carvalho Filho (2012) finds a similar result for Brazil. A higher anticipated income decreases child labor and increases school attendance, even if this income is only promised, but not yet delivered (Edmonds, 2006).

Carneiro and Heckman $(2002,2003)$ show that while there is certainly a relationship between short-term income and school attendance (in their study, going to college), long-term income is more important. They offer two explanations for this. The first is a credit restriction that does not allow the financing of the child's education; the second is the inability of the child to buy an environment in the home that allows him to succeed in school, such as a family environment that is favorable to the education of children, and to the formation of attitudes and social skills. They find that these latter factors affect school attendance more than the income or credit restriction in the short term. 


\section{Education}

The education of parents is one of the ways to create a better environment for children and to improve school attendance (Chevalier et al., 2013). There are channels through which the higher education of parents can lead to more education of their children. First, parents that are more educated can be more efficient in the production of human capital of their children (Becker et al. 2015; Spenkuch, 2015). In addition, parents with more education dedicate more time to their children ( Guryan et al., 2008; Campaña et al., 2017; Dotti Sani and Treas, 2016). Moreover, children of more educated parents achieve higher test scores (Davis-Kean, 2005). Finally, perhaps more educated parents have better information about future returns to the education of their children, while less educated parents underestimate future returns to education (Jensen, 2010; Kaufmann, 2014). It is also possible that the education of parents generates a wealth effect that also provides information on the returns to education of children (Chernikovsky and Meesook, 1985).

\section{Government policies}

In Mexico, government policy in the fight against poverty and in favor of children's school attendance was carried out through the Oportunidades-Progresa program, which began in $1997^{3}$. The program is specifically designed to promote school attendance among the low-income population (Levy, 2007)). This program, while increasing household income through a transfer of money, conditions such transfer to the children of the household attending school. ILO (2013, p. Xvii) found that conditional transfers reduced child labor by up to $10.4 \%$ in the case of Cambodia. The Oportunidades program has been effective in both reducing child labor and in increasing

\footnotetext{
${ }^{3}$ The Progresa program was established in 1997. It was later termed Oportunidades in 2004 and more recently in 2014 it was rebranded as the Prospera Program. We refer to this program through its different phases as Oportunidades in this paper.
} 
school attendance in Mexico (Behrman et al. 2005; Schultz, 2004; Skoufias and Parker, 2001). In the year 2000 the Oportunidades program was small, which allows us to study the effects of the growth of the program on child labor between the years 2000 and 2010.

Another relevant government policy relates to the access of individuals to public health institutions. In 2004, the "Seguro Popular" was instituted in Mexico. Seguro Popular provides health insurance for the population that is not covered in the formal sector of the economy. Until 2004, the population's access to public health institutions (Seguro Social) was given to workers (and their families) through firms registered in the formal sector of the economy. The workers in the informal sector (and their families) did not have access to public health insurance before Seguro Popular ${ }^{4}$. Individuals could purchase private health insurance, but it was generally inaccessible to workers in the informal sector given its high cost. We refer to this access to public health institutions either through the formal (Seguro Social) or informal (Seguro Popular) sector as social health insurance. It is possible that with the expansion of social health insurance into households not covered in the formal sector of the economy, such households improved their health human capital and their contact with social institutions. This could lead to a fall in child labor and an increase in school attendance, even though said households are still part of the informal economy. Additionally, one could also link the size of the formal sector to child labor and school attendance. Although child labor is prohibited in Mexico until age 14 and compulsory education extends to age 17 , child labor prohibitions have a smaller impact on economies that have a significant percentage of informal work ${ }^{5}$. We observe a reduction of the formal sector of the economy between

\footnotetext{
${ }^{4} \mathrm{We}$ consider formal workers those whose work is within the legal and regulatory framework that encompasses Seguro Social (social security) as in Levy and Székely (2016) and Levy (2008). Seguro Social refers to the federal government organizations that administer Mexico's health care and social benefits, giving access to such benefits to workers of companies registered in the formal sector of the economy. These organizations are Instituto Mexicano del Seguro Social (IMSS) and Instituto de Seguridad Social y Servicios Sociales de los Trabajadores del Estado (ISSSTE). The benefits are given through the companies and are controlled by the government and the laws. ${ }^{5}$ Between 2000 and 2010 child labor was prohibited in Mexico until age 13.
} 
the years 2000 and 2010, which could have led to an increase in child labor and a decrease in school attendance. Ultimately, the overall effect of the changes in access to social health insurance on child labor and school attendance is an empirical question.

\section{Remittances}

Remittances are an additional source of income received by migrant households, which is important in the case of Mexico. Mexico is one of the largest recipients of remittances as recorded by the World Bank (Ratha et al. 2016), and one of the countries with the largest number of emigrants, 13.2 million in $2013,10.7 \%$ of its population. Since the reception of remittances often implies the absence of the father and/or the investment in small family businesses that can occupy child labor, the effect of remittances on child labor and school attendance is ambiguous. Alcaraz et al. (2012) find the increase in remittances has contributed to reducing child labor in Mexico. Yang (2008) finds a similar result for the Philippines. Cox Edwards and Ureta (2003) find that

remittances increase school retention by more than income does in El Salvador; while Acosta (2011) does not find clear effects for the same country. Hanson and Woodruff (2003) and Antman (2012) find an effect of U.S. migration on education for Mexican households.

\section{Demographic Changes in the Household}

Household size and thus the percentage of children in the household can be important determinants of child labor. Basu and Van (1998) model that a smaller household can lead to less child labor, which is confirmed by Patrinos and Psacharopoulos $(1995,1997)$ in the case of Peru and Paraguay. Between the years 2000 and 2010, household size in Mexico decreased resulting in less children per household, which could have led to the decrease in child labor.

\section{Data}


We use the Population and Housing Census of Mexico for 2000 (INEGI, 2004) and 2010 (INEGI, 2012). The Census samples comprise $10 \%$ of the population, with more than 9.4 million individual cases in 2000 and more than 11.9 million in 2010. We study children between 12 and 14 years of age, as the Census does not provide work information for younger children. In both the Population Census of years 2000 and 2010 (INEGI, 2012), the population of 12 years and older is asked: “La semana pasada ¿Trabajó, por lo menos una hora?” ("Last week did you work for at least one hour?"). For individuals who responded they were engaged in other activities such as studying, working at home, etc., the surveyor asks again if they worked, and if their occupation is another activity but they worked, they are classified as workers.

We define household income as the income of adult household members (aged 18 and over). Household income is important if children only work when the income of the household is not sufficient to cover basic needs (Basu and Van, 1998). One of the issues faced is that out of the sample of the population aged 12 to $14,12 \%$ of urban households and $40 \%$ of rural households do not declare income in 2000 (11\% and 41\%, respectively, in 2010). The households who declare zero income are not those with lower education, but rather these households are distributed along years of education of the head of the household, possibly because the income information is denied to the surveyor at all income levels. Therefore, zero income does not correspond to low-income households and cannot be attributed to poverty; hence we exclude these households from our study. We also exclude households for which we have no information on the years of education of the head of the household.

The Censuses provide information on the labor income of each household member, the size of the household, if adults have access to social health insurance, if the household receives support from government programs such as the Oportunidades program, if the household receives 
remittances, the years of schooling of the head of the household, etc. While the 2000 Census provides quantitative information on income from remittances and from government assistance, the 2010 Census only provides qualitative (yes/no) information, hence we include these two variables in the study as indicator variables.

The variables we use in our analysis are defined as follows. School attendance refers to whether the child (aged 12-14) attends school. Child labor refers to whether the child (aged 1214) works. Edu. Head are the years of education of the head of the household. Log PCI is the logarithm of the household's per capita income, defined as the income of adult household members divided by the total number of household members (consistent with the definitions in Basu and Van (1998)). Govt. help is equal to one for households that receive monetary assistance from government programs and zero otherwise. Remittances equals one if the household receives remittances, and zero otherwise. Social Health Insurance equals one if the household receives social health insurance (either through Seguro Social or Seguro Popular), and equals zero otherwise. Age refers to the age of the child (either 12, 13 or 14). Household size is the number of members in the household. Finally, \% Children indicates the proportion of children in the household.

\section{Per capita income, child labor and school attendance.}

Per capita income is widely used in the literature as an important determinant of child labor; we start by studying the relation between per capita income, child labor and school attendance. We compute kernel regressions, the local linear estimator, using Gaussian kernels of order two (between the log of per capita income and the proportion of children working or attending school). We use package "np" of Hayfield and Racine (2008, version 2017) in R. To estimate kernels, we 
use local linear estimators and use cross-validation of least squares to select bandwidths. We do this for the full sample and subdivide by sex and population size, where we define as rural those populations under 15,000 inhabitants, and as urban those with more than 15,000 inhabitants.

The relation between per capita household income with child labor and with school attendance is shown in Figure 1. The horizontal axis measures the logarithm of household per capita income and the vertical axis measures the percentage of children working (left side figures) and the percentage of children attending school (right side figures). We observe lower income relates to more child labor and less school attendance. The vertical lines represent the quantiles of income per capita of 25,50 and $75 \%$. For each income level up to the third quartile there is a reduction in child labor and an increase in school attendance between 2000 and 2010. For the fourth quartile there are no significant changes in school attendance between 2000 and 2010, implying that the improvement in school attendance comes from households with lower per capita income.

Panels B-D in Figure 1 correspond to four subsamples created by subdividing the sample according to sex and size of the locality. The panels show children aged 12 and 14 (13 year olds are excluded to simplify the visualization of the curves). We observe older children are associated with more child labor and less school attendance. The steeper the slope of the lines, the greater the role of permanent income (Carneiro and Heckman, 2002). Therefore, lines with close to horizontal slopes indicate that the proportion of child labor (or school attendance respectively) does not depend on per capita income. We observe this in the case of child labor for both 12-year-old boys and girls in urban areas in 2010. We also note social progress between the years 2000 and 2010, as we observe a clear decrease in child labor and an increase in school attendance in all cases (boys and girls, rural and urban, 12 and 14 year olds). 
The strength of the reduction in child labor and the increase in school attendance varies depending on age and sex. For instance, for 12-year-old urban boys the reductions in child labor in the 25 th, 50th and 75 th percentiles are $4.3,4.1$ and 2.3 percentage points respectively, while the increase in school attendance is 1.7, 1.9 and 1.4 percentage points. In contrast, for 12-year-old girls in the rural sector we see reductions in child labor in the 25 th, 50 th and 75 th percentiles of $2.3,1.9$ and 1.4 percentage points respectively, with increases in school attendance of $6.1,5.5$ and 3.1 percentage points. While the reduction in child labor is stronger than the increase in school attendance for 12-year-old rural boys, the increase in school attendance is stronger for rural girls. If we did not distinguish boys from girls and rural from urban sectors we would observe similar increases in school attendance to the reductions in child labor ${ }^{6}$.

\section{Methodology of Decomposition}

We now turn to the question of what has led to the reduction in child labor and the increase in school attendance in Mexico, between the years 2000 and 2010. To answer this, we utilize the method in Fairlie (2005) implemented by Jann (2006) in Stata. The method is based on the decomposition of Oaxaca (1973) and Blinder (1973). This method allows the difference in the variable of interest between two groups to be broken down into two components: the first due to differences in the explanatory variables, and the other due to differences in group processes in determining the levels of the variable of interest and to unmeasurable and/or unobserved endowments. Fairlie (2005) provides an extension of the Blinder-Oaxaca decomposition technique for the case in which the outcome variable is binary, using estimates from a logit or probit model.

\footnotetext{
${ }^{6}$ If we take all children aged $12-14$, the reduction in child labor in the 25,50 and $75^{\text {th }}$ percentiles is of $5.3,4.7$ and 1.7 percentage points, respectively, while the increase in school attendance is of 5.6, 5.3 and 1.4 percentage points in the same percentiles.
} 
We use Fairlie's (2005) decomposition method as we are looking for the causes of the differences in school attendance and child labor over time, where both child labor and school attendance are binary variables.

Following Fairlie (2005), the decomposition for a non-linear equation is:

$$
\bar{T}_{2000}-\bar{T}_{2010}=\left[\sum_{i=1}^{N_{2000}} \frac{F\left(X_{2000}^{i} \hat{\beta}_{2000}\right)}{N_{2000}}-\sum_{i=1}^{N_{2010}} \frac{F\left(X_{2010}^{i} \hat{\beta}_{2000}\right)}{N_{2010}}\right]+\left[\sum_{i=1}^{N_{2000}} \frac{F\left(X_{2010}^{i} \hat{\beta}_{2000}\right)}{N_{2010}}-\sum_{i=1}^{N_{2010}} \frac{F\left(X_{2010}^{i} \hat{\beta}_{2010}\right)}{N_{2010}}\right] \text { (1) }
$$

$\mathrm{Tj}$ is the dependent variable, either child labor or school attendance, in year $\mathrm{j}$. This variable takes a value of either 1 (if the child works or attends school) or 0 (if they do not), the average value is $\bar{T}_{j}$. Nj refers to the size of the census sample in year $\mathrm{j}, \mathbf{X}$ is a vector of explanatory variables, $\boldsymbol{\beta}$ is the vector of estimated coefficients, and year $\mathrm{j}$ can be either 2000 or 2010 . The first term on the right side of the equation refers to the portion of the difference in the proportion of children working (attending school) between 2000 and 2010 that is due to the differences in the distributions of $\mathrm{X}$ between the two years, valued in year 1, and the second term refers to the difference that originates from the different $\boldsymbol{\beta}$ assessments of each year and to unexplained items. Because our focus is the effect of changes in policies, changes in the means of the variables and not in the changes in the estimated parameters, we focus on the first term of the equation. If the model only had three variables and if $\mathrm{N}_{2000}=\mathrm{N}_{2010}$, the independent contribution of $\mathrm{X}_{1}$ to the differences in child labor (school attendance) $\bar{T}_{2000}-\bar{T}_{2010}$ could be found as ${ }^{7}$ :

$$
\frac{1}{N_{2000}} \sum_{i=1}^{N_{2000}} F\left(\hat{\alpha}^{*}+X_{1,2000}^{i} \hat{\beta}_{1}^{*}+X_{2,2000}^{i} \hat{\beta}_{2}^{*}+X_{3,2000}^{i} \hat{\beta}_{3}^{*}\right)-F\left(\hat{\alpha}^{*}+X_{1,2010}^{i} \hat{\beta}_{1}^{*}+X_{2,2000}^{i} \hat{\beta}_{2}^{*}+X_{3,2000}^{i} \hat{\beta}_{3}^{*}\right)
$$

In other words, the contribution of each variable to the differences in child labor (school attendance) between 2000 and 2010 is equal to the change in the average predicted probability if

\footnotetext{
${ }^{7}$ For a discussion of the methodology see Fairlie and Robb (2007) and Fairlie (2005, 2017).
} 
we replace the 2000 distribution for the 2010 distribution for that variable, while maintaining the distributions of the other variables constant. We can similarly obtain the contributions of the other variables to the differences in child labor (school attendance); the sum of such contributions from all variables is equal to the first term of the equation (1).

We follow Farlie's (2005) decomposition technique. Because using the year 2000 or 2010 as the base year can lead to different estimates (Cain, 1986), we pool the observations of both years to estimate the $\beta *$ coefficients using Logit models. We then calculate the predicted probability of a child working/attending school, for each observation in the sample. The two groups need to be of equal size, so we take a random subsample of the larger group. Then, we separately rank each observation in the 2000 sample and the 2010 sample according to the predicted probabilities, and match each observation in the 2000 sample to an observation in the 2010 sample. We use the one-

to-one matches to get the independent contribution of $\mathrm{X}_{1}$, to the differences in child labor (school attendance) between 2000 and 2010; then we get the independent contribution of $\mathrm{X}_{2}$, and so on. We then start again by taking another random subsample of the larger group, while randomizing the order of the variables at the same time. We do 1000 replicas of the decomposition, and calculate the mean value of estimates from the separate decompositions, which is what is reported in the tables.

\section{Results}

\subsection{Full Sample}

The mean values for the characteristics of households with children aged 12 to 14 are shown in Table 1. Panel A subdivides the sample by whether the child works and/or attends school. In the year 2000 , only $49 \%$ of children who worked also attended school, a percentage that 
increases to $54 \%$ in 2010 . Additionally, out of those children who did not attend school, $35 \%$ worked in 2000 while $27 \%$ worked in 2010. Between 2000 and 2010 there was a decrease in child labor (for both children who attended school and those who did not), and there was an increase in school attendance (for both children who worked and those that did not).

Compared to homes of children who work, we observe that in homes of children who do not work the education of the head of the household and income are higher, as is access to social health insurance. In a similar fashion, in homes of working children government help and remittances are higher, and these homes are also larger (household size) and have a greater proportion of children. The same can be said about school attendance. Compared to children who do not attend school, children who attend school live in households where the head of the household has more education, there is higher income and more access to social health insurance. Children who do not attend school live in households with more government help and more remittances, larger households and with a larger proportion of children in the home.

Panel B of Table 1 separates households by the size of locality. The factor that is most changed between 2000 and 2010 is government aid (Govt. Help), as in the year 2000 the Oportunidades program barely existed in the urban sector and it had grown by 2010. Remittances also increased significantly, but the percentage of the population that receive them is small. Per capita income (PCI) increased by $29 \%$ in the urban sector and $48 \%$ in the rural sector, but in terms of logarithms the increase is $3.5 \%$ in the rural sector and $6.2 \%$ in the rural sector $(\log P C I)$. In the rural sector, the fraction of households with access to Social Health Insurance more than doubled. We also note a decrease in the size of the household and in the percentage of children in the household, between 2000 and 2010. All differences between 2000 and 2010 are significantly different from zero at the $1 \%$ level. Because some of the variables differed significantly between 
rural and urban households, we expect the factors responsible for the decrease in child labor and school attendance in the rural/urban sectors to also differ ${ }^{8}$.

The Logit estimates ${ }^{9}$ indicate that more education of the head of the household, per capita income, government assistance and social health insurance tend to decrease child labor, and to increase school attendance. Additionally, the reduction in family size and in the percentage of children in households also contribute to reducing child labor and increasing school attendance. Remittances, which as discussed earlier could both increase or decrease child labor and school attendance, are found to increase the probability of a child working and decrease the probability of a child attending school.

Table 2 shows the results of the decomposition of the influence of each variable on the change in child labor and school attendance. We construct four subsamples according to if the child is a boy or girl, and whether they live in the rural or urban sector. As an example, taking boys in the urban sector (column 1), the proportion of boys working was $8.3 \%$ in 2000 and $5.0 \%$ in 2010, a reduction of 3.3 percentage points. Of this fall in child labor, changes in the variables explain 1.9 percentage points, or $58 \%$ of the fall. The explained fall in child labor is $67 \%$ due to the increased education of the head of the household, $5 \%$ due to the improvement in income, $13 \%$ due to more government assistance, etc. ${ }^{10}$. Demog refers to demographic variables included depending on the specification: household size, fraction of children in the household, rural or urban sector, and age.

The findings indicate that the increased education of the head of the household is the most important variable that explains both the reduction in child labor and the increase in school

\footnotetext{
${ }^{8}$ The mean values of the explanatory variables are the same for boys and girls.

${ }^{9}$ The Logit model results are shown in the Appendix.

${ }^{10}$ The sum of the percentage values is $100 \%$, including the negative values due to the variable state, and in some cases the variable remittances.
} 
attendance between the years 2000 and 2010 . This is followed by the increase in government assistance and greater access to social health insurance. These last two variables are particularly important in the case of both boys and girls in the rural sector.

\subsection{Results by age and sex}

We next partition the sample into subsamples according to age $(12,13$ or 14$)$ and sex in Table 3. A larger proportion of boys worked in year 2000 compared to girls, and we observe a stronger reduction in child labor in the case of boys than girls. Increases in school attendance between 2000 and 2010 are similar for boys and girls. The greatest improvements are shown in the case of 14-year-old boys and girls, perhaps because they are the ones with a higher proportion of child labor and a lower proportion of school attendance compared to 12 or 13 year olds.

Once again, we find the improved education of the head of the household is the most important cause of the fall in child labor and the increase in school attendance, followed by improved access to social health insurance. Income per capita and remittances explain very little (if any) of the differences in child labor and school attendance. Family characteristics such as household size and the percentage of children in the home are more important as children get older. Changes in government monetary assistance also explain the changes in school attendance and child labor. Further, in the case of explaining differences in child labor, government assistance played a more important role in the case of girls than boys. The negative sign of income for 12year-old girls, in the case of child labor, is consistent with the observation of horizontal lines in Figure 1 for the rural sector, and implies that per capita income does not explain the 2000-2010 differences in child labor for 12-year-old girls. 


\subsection{Results by incidence of poverty of the state}

In economic models income is the most important factor influencing child labor, and empirical evidence shows low income to be strongly associated with more child labor and less school attendance. However, the findings here (Table 2) indicate that among children in urban households the most important factor that led to a reduction in child labor and to an increase in school attendance was the improvement in the education of the head of the household. Among rural children, access to social health insurance and government assistance also play an important role. We now partition the sample by the incidence of poverty of the state, to explore whether in states where there are higher concentrations of low-income residents we can find stronger income effects, and hence income as a more important factor influencing changes in child labor and school attendance in those states.

We classify states into one of five groups according to the incidence of poverty of the population. We take the minimum welfare lines according to the National Council for the Evaluation of Social Development Policy (CONEVAL) of Mexico to define poverty. The welfare lines are defined in pesos and measure the value of the minimum "food basket" for one person. The value of such welfare lines as of November 2017 was of $\$ 1.88$ dollars per person per day for the rural sector and of $\$ 2.64$ dollars for the urban sector. We use the poverty lines for 2000 and 2010 (CONEVAL, 2017) to calculate the percentage of the population in poverty in each state in 2000 and 2010. For example, in Mexico City 5.8\% and 6\% of the population fell under the poverty line in 2000 and 2010 respectively; while in Chiapas 53.3\% and 51\% of the population fell under the poverty line for the same years. We then average the two years to define the poverty level of 
each state. Next, we group states into five groups according to the percentage of the population in poverty in the state, such groups are shown in Table $4^{11}$.

The averages of the variables by poverty level of the states are shown in Table 5, where group 1 indicates group of states with the lowest percentage of population in poverty and group 5 indicates the group of states with the highest percentage of population in poverty. The differences in the averages between 2000 and 2010 are significantly different from zero at the $1 \%$ level for all variables and all groups, except where noted. For all state-poverty groups we observe a fall in child labor between 2000 and 2010. The table shows strong changes in terms of school attendance, income, and access to social health insurance. There is also a strong increase in government aid and remittances among the low-poverty states.

Table 6 shows the decomposition results by state-poverty group. As before, education of the head of the household is the most important factor that explains both the decrease in child labor and the increase of school attendance. As expected, the importance of this factor is lower in highpoverty states. For instance, the education of the head of the household explains $60 \%$ of the change in child labor and $68 \%$ of the change in school attendance in the low-poverty group of states (group 1), but only $35 \%$ of the changes in the high-poverty states (group 5). Among the high-poverty states, access to social health insurance is the second most important factor. Access to social health insurance increased significantly for this group, from $30 \%$ to $61 \%$ (Table 6). Government assistance also plays an important role, particularly in terms of the increase in school attendance in high-poverty states.

\footnotetext{
${ }^{11}$ In forming groups, we look for states that are similar in terms of the percentage of population which is poor, and place them in a group.
} 


\subsection{Results by type of access to social health insurance}

The strong improvement in access to social health insurance between 2000 and 2010, especially within high-poverty states, was an important factor in the decrease in child labor and the increase in school attendance, second only to the improvement of the education of the head of household. We subdivide households into those with access to health insurance that is provided through Seguro Social (the formal sector), Seguro Popular (the informal sector), and households without access to health insurance provided by the State.

Table 7 shows that households with no access to social health insurance are predominantly in the high-poverty states, and go from $69 \%$ in 2000 to $39 \%$ in 2010 . This decrease is due in large part to the expansion of Seguro Popular, which started in 2004. In the high-poverty states 35\% of households in the informal sector gain access to health care through Seguro Popular, while there is a decrease in the population covered in the formal sector from $31 \%$ to $26 \%$. The fall in the percentage of households with access to social health care in the formal sector (Seguro Social) occurs across all groups of states. Given this observed reduction of the formal sector, one would expect an increase in child labor and a fall in school attendance between 2000 and 2010; thus the observed fall in child labor and increase in school attendance cannot be explained by the change in the formal sector.

Table 8 shows the decomposition results separating social health insurance into the two groups: Seguro and Seguro Popular. Education of the head of the household is still the most important variable explaining changes in child labor and school attendance. Seguro Social (the formal sector) takes a negative sign, and the expansion in Seguro Popular is the second most important factor explaining changes in the high-poverty states. Therefore, the implementation of Seguro Popular, which gives access to social health insurance to workers in the informal sector 
and to their families, had an important effect on the fall in child labor and the increase in school attendance in Mexico between 2000 and 2010. It is possible that the now available access to social health insurance improved the health human capital and the link to social institutions of households. In the formal sector of the economy, there was a decrease in the households with access to social health insurance, so such change cannot explain the observed changes in child labor and school attendance. However, this does not mean that access to Seguro Popular is more important to changes in child labor and school attendance than an extra job in the formal sector (Seguro Social). We estimate the importance of each individual factor to changes in child labor and school attendance using the results of the Logit model (Tables A7 and A8 in the Appendix). Table 9 shows the marginal values of an increase in Seguro Social (and therefore an increase in the formal sector) or an increase in the Seguro Popular, following the methodology in Williams (2012). Individuals are identical in all aspects, except for one individual having access to social security and the other access to Seguro Popular. Among the low-poverty states (group 1), access of the household to health insurance through the formal sector (Seguro Social) lowers the probability that a child works by 0.0096 while access to health insurance through the informal sector (Seguro Popular) lowers it by 0.0068. In a similar fashion, access to Seguro Popular increases the probability of a child going to school by less than a third of what access to the formal sector (Seguro Social) would increase it (0.0165 vs 0.0053). For households in the high-poverty states (group 5), the probability that a child works falls by 0.0278 for children in a household with access to health insurance through the formal sector and by 0.0200 for those in a household with access to health insurance thorough the informal sector (Seguro popular). In terms of school attendance, the effect of Seguro Popular is less than half of the effect of Seguro Social (a job in the formal sector). The fall in the likelihood of a child working as the household gains access to 
social health insurance either through the formal or the informal sector is stronger in the highpoverty states. The reduction in the probability that a child works is approximately $40 \%$ stronger for households in the formal vs. the informal sector when they gain access to social health insurance. On the other hand, the probability of school attendance is more than double when the household gains access to the formal sector vs only receiving Seguro Popular. These effects are much stronger among high-poverty states.

\section{Robustness Checks}

\subsection{Relations between education and income}

Years of education of the head of the household is the most important factor explaining the fall in child labor and the increase in school attendance in Mexico, however it is correlated with other explanatory variables like current per capita income, for example. In theoretical terms, Chevalier et al. (2013) relate it to permanent income, and Carneiro and Heckman (2002, 2003) would place it among the factors that make the child's education more favorable. In addition to influencing income, education influences the size of the household and the number of children, and can be decisive in obtaining social health insurance and in obtaining government assistance. A potential concern is that education of the head of the household absorbs the information contained in the income ( $\log$ PCI) variable, and for this reason education of the head of the household is the most important factor explaining the changes in child labor and school attendance, while income plays a minor role. To evaluate this possibility, we remove education of the head of the household from the analysis, and focus on the influence of the other factors in explaining changes in child labor and in school attendance between 2000 and 2010. 
Specifications (1) and (4) in Table 10 include all explanatory factors, specifications (2) and (5) exclude the income variable, and specifications (3) and (6) exclude education of the head of the household ${ }^{12}$. The first two rows of the Table show the Likelihood Ratio (LR) and the Pseudo $\mathrm{R}^{2}$ of the logistic regressions (full results are shown in the Appendix). When income is excluded from the regression the values of the $L R$ and of the Pseudo $\mathrm{R}^{2}$ barely change compared to when it is not excluded, indicating that the information of the per capita income was already captured by the other explanatory variables. However, the LR and the Pseudo $\mathrm{R}^{2}$ substantially fall when we exclude the variable referring to education, which indicates that not all of the information in education is captured by the rest of the variables. The bottom section of the Table refers to Fairlie's (2005) decomposition results. Excluding education of the head of the household from the analysis, income explains $31 \%$ of the changes in child labor and $37 \%$ of the changes in school attendance, which is significantly more than what was shown in Table 2 . Therefore, the information in current income was being captured by education of the head of the household. Under this specification social health insurance is as important (or more) than income in explaining the changes in child labor and school attendance. In addition, the importance of demographic variables (Demog) such as household size and the number of children increases. In summary, if we exclude education of the head of the household from the analysis, then income, social health insurance, and demographic variables explain the 2000-2010 changes in child labor and school attendance.

Table 11 repeats the decomposition separating by the poverty level of the states, while excluding the education of the head of the household from the analysis. The table shows the percentage of the change explained by each factor. In this case, among the states with high incidence of poverty, expansion in social health insurance is the most important factor that explains

\footnotetext{
12 Columns (3) and (6) exclude observations with missing values for years of education of the head of household in line Pr2000.
} 
the decrease in child labor and the improvement in school attendance, followed by per capita income. We also observe that having a smaller household size and a lower fraction of children in the home (Demog) was important to the fall in child labor and the increase in school attendance, mainly in states with low incidence of poverty.

\section{Conclusion}

Between the years of 2000 and 2010 Mexico experienced a decrease in child labor and an increase in school attendance of children 12 to 14 years of age. We show that the decrease in child labor and increase in school attendance is consistent among sex (girls and boys), age (12, 13 and 14 year olds), locality (rural and urban sectors) and state poverty level (from low-poverty states to high-poverty states). The main purpose of this paper is to evaluate the factors that led to such drop in child labor and increase in school attendance.

We consider the following factors. (1) increased income, (2) an improvement in the education of family members, in particular, the head of the household, (3) improved access to social health insurance, (4) increased governmental support, for instance support from the Oportunidades program (5) increased income from remittances, and (6) demographic factors, such as smaller household and a smaller fraction of children in the household.

Overall, the most relevant variable that explains the fall in child labor and the increase in school attendance is the improved education of the head of the household. The years of education of the head of the household increased by $19 \%$ in urban households and by $37 \%$ in rural households in the sample between 2000 and 2010. Among households with working children, education of the head of the household increased by $38 \%$, and it increased by $51 \%$ among households who had a child not attending school. 
Education of the head of the household affects child labor and school attendance both directly and indirectly through its effects on per capita income, access to public health institutions, and the number of children in a household, and possibly the greatest attention to each of them. Our study suggests that public policies aimed at increasing school attendance and those aimed at decreasing child labor should consider the improvement of education as a major goal.

\section{References}

Acosta, P. (2011). School Attendance, Child Labour, and Remittances from International Migration in El Salvador. The Journal of Development Studies, 47(6), 913-936. doi:10.1080/00220388.2011.563298

Alcaraz, C., Chiquiar, D., \& Salcedo, A. (2012). Remittances, schooling, and child labor in Mexico. Journal of Development Economics, 97(1), 156-165.

Antman, F. M. (2012). Gender, educational attainment, and the impact of parental migration on children left behind. Journal of population economics, 25(4), 1187-1214.

Baland, J.-M., \& Robinson, J. A. (2000). Is child labor inefficient? Journal of Political Economy, 108(4), 663-679.

Basu, K., \& Van, P. H. (1998). The economics of child labor. American Economic Review, 412427.

Becker, G. S. (1967). Human capital and the personal distribution of income: An analytical approach. W. S. Woytinksy Lecture In G. S. Becker (Ed.), Human capital: a theoretical and empirical analysis, with special reference to education (pp. 94-117). Chicago: University of Chicago.

Becker, G. S., Kominers, S. D., Murphy, K. M., \& Spenkuch, J. L. (2015). A theory of intergenerational mobility.

Becker, G. S., \& Murphy, K. M. (1988). The family and the state. The Journal of Law and Economics, 31(1), 1-18.

Behrman, J. R., Sengupta, P., \& Todd, P. (2005). Progressing through PROGRESA: An impact assessment of a school subsidy experiment in rural Mexico. Economic Development and Cultural Change, 54(1), 237-275.

Blinder, A. S. (1973). Wage Discrimination: Reduced Form and Structural Estimates. The Journal of Human Resources, 8(4), 436-455. doi:10.2307/144855

Cain, G. G. (1986). The economic analysis of labor market discrimination: A survey. Handbook of labor economics, 1, 693-785.

Campaña, J. C., Gimenez-Nadal, J. I., \& Molina, J. A. (2017). Increasing the Human Capital of Children in Latin American Countries: The Role of Parents' Time in Childcare. The Journal of Development Studies, 53(6), 805-825. doi:10.1080/00220388.2016.1208179 
Carneiro, P. M., \& Heckman, J. J. (2002). The evidence on credit constraints in post-secondary schooling. The Economic Journal, 112(482), 705-734.

Carneiro, P. M., \& Heckman, J. J. (2003). Human capital policy. In J. Heckman \& A. Krueger (Eds.), Inequality in America. . Cambridge: MIT Press.

Chernikovsky, D., \& Meesook, O. A. (1985). School enrollment in Indonesia: The World Bank.

Chevalier, A., Harmon, C., O’Sullivan, V., \& Walker, I. (2013). The impact of parental income and education on the schooling of their children. IZA Journal of Labor Economics, 2(1), 8.

CONEVAL. (2017). "Líneas de Bienestar México 1992 (enero) a 2017 (noviembre). Evolución de las líneas de bienestar y de la canasta alimentaria. Retrieved from: http://www.coneval.org.mx/Medicion/Documents/Lineas_bienestar/Lineas_Bienestar.zip

Cox Edwards, A., \& Ureta, M. (2003). International migration, remittances, and schooling: evidence from El Salvador. Journal of Development Economics, 72(2), 429-461. doi:https://doi.org/10.1016/S0304-3878(03)00115-9

Davis-Kean, P. E. (2005). The influence of parent education and family income on child achievement: the indirect role of parental expectations and the home environment. Journal of family psychology, 19(2), 294.

De Carvalho Filho, I. E. (2012). Household income as a determinant of child labor and school enrollment in Brazil: Evidence from a social security reform. Economic Development and Cultural Change, 60(2), 399-435.

Dotti Sani, G. M., \& Treas, J. (2016). Educational gradients in parents' child-care time across countries, 1965-2012. Journal of Marriage and Family, 78(4), 1083-1096.

Edmonds, E. V. (2005). Does child labor decline with improving economic status? Journal of Human Resources, 40(1), 77-99.

Edmonds, E. V. (2006). Child labor and schooling responses to anticipated income in South Africa. Journal of Development Economics, 81(2), 386-414.

Edmonds, E.V. (2008). Child Labor. Handbook of Development Economics, Elsevier.

Edmonds, E. V., \& Schady, N. (2012). Poverty alleviation and child labor. American Economic Journal: Economic Policy, 4(4), 100-124.

Fairlie, R. W. (2005). An extension of the Blinder-Oaxaca decomposition technique to logit and probit models. Journal of Economic and Social Measurement, 30, 305-316.

Fairlie, R. W. (2017). Addressing Path Dependence and Incorporating Sample Weights in the Nonlinear Blinder-Oaxaca Decomposition Technique for Logit, Probit and Other Nonlinear Models. SIEPR Working Paper. Stanford University. Stanford. Retrieved from https://siepr.stanford.edu/research/publications/addressing-path-dependence-andincorporating-sample-weights-nonlinear-blinder

Fairlie, R. W., \& Robb, A. M. (2007). Why are black-owned businesses less successful than white-owned businesses? The role of families, inheritances, and business human capital. Journal of Labor Economics, 25(2), 289-323.

Grootaert, C., \& Kanbur, R. (1995). Child labour: an economic perspective. Int'l Lab. Rev., 134, 187.

Guryan, J., Hurst, E., \& Kearney, M. (2008). Parental education and parental time with children. Journal of Economic Perspectives, 22(3), 23-46. 
Hanson, G. H., \& Woodruff, C. (2003). Emigration and educational attainment in Mexico. Retrieved from http://www.childmigration.net/files/Hanson_2003.pdf

Hayfield, T., \& Racine, J. S. (2008). Nonparametric econometrics: The np package. Journal of statistical software, 27(5), 1-32.

ILO. (2013). World report on child labour: Economic vulnerability, social protection and the fight against child labour Geneva: International Labour Office. Geneva: ILO.

INEGI. (2004). XII Censo General de Población y Vivienda 2000. from Instituto Nacional de Estadística y Geografía http://www.beta.inegi.org.mx/proyectos/ccpv/2000/default.html http://www.inegi.org.mx/inegi/default.aspx?s=est\&c=10202

INEGI. (2012). Censo de Población y Vivienda 2010. Retrieved July 13, 2018, from Instituto Nacional de Estadística y Geografía http://www.beta.inegi.org.mx/proyectos/ccpv/2010/

Jann, B. (2006). fairlie: Stata module to generate nonlinear decomposition of binary outcome differentials. Retrieved from http://ideas.repec.org/c/boc/bocode/s456727.html.

Jensen, R. (2010). The (perceived) returns to education and the demand for schooling. The Quarterly Journal of Economics, 125(2), 515-548.

Kaufmann, K.M. (2014). Understanding the income gradient in college attendance in Mexico: The role of heterogeneity in expected returns. Quantitative Economics 5,583-630.

Levy, S. (2008). Good Intentions, Bad Outcomes. Social Policy, Informality, and Economic Growth in Mexico (1st ed.). Washington, D.C.: Brookings Institution Press.

Levy, S. (2007). Progress against poverty: sustaining Mexico's Progresa-Oportunidades program: Brookings Institution Press.

Levy, S., \& Székely, M. (2016). ¿ Más escolaridad, menos informalidad? Un análisis de cohortes para México y América Latina. El Trimestre Económico, 83(332), 499-548.

Oaxaca, R. (1973). "Male-Female Wage Differentials in Urban Labor Markets". "International Economic Review", 14, "693-709".

Patrinos, H. A., \& Psacharopoulos, G. (1995). Educational performance and child labor in Paraguay. International Journal of Educational Development, 15(1), 47-60. doi:https://doi.org/10.1016/0738-0593(94)E0001-5

Patrinos, H. A., \& Psacharopoulos, G. (1997). Family size, schooling and child labor in Peru-An empirical analysis. Journal of population economics, 10(4), 387-405.

Psacharopoulos, G. (1997). Child labor versus educational attainment. Some evidence from Latin America. Journal of population economics, 10(4), 377-386.

Ratha, D., Eigen-Zucchi, C., \& Plaza, S. (2016). Migration and remittances Factbook 2016: World Bank Publications.

Ravallion, M., \& Wodon, Q. (2000). Does child labour displace schooling? Evidence on behavioural responses to an enrollment subsidy. The Economic Journal, 110(462), 158175.

Schultz, T. P. (2004). School subsidies for the poor: evaluating the Mexican Progresa poverty program. Journal of Development Economics, 74(1), 199-250.

Skoufias, E., \& Parker, S. W. (2001). Conditional Cash Transfers and Their Impact on Child Work and Schooling: Evidence from the PROGRESA Program in Mexico. Economica(Fall), 45-96.

Spenkuch, J. L. (2015). Intergenerational Mobility and Income Inequality. In Inequality and Economic Policy: Essays in Memory of Gary Becker: Hoover Institution. 
Yang, D. (2008). International migration, remittances and household investment: Evidence from Philippine migrants' exchange rate shocks. The Economic Journal, 118(528), 591-630. 
Figure 1. Relation of log per capita household income with child labor and school attendance.

\section{Panel A. Full Sample}

\% Child Labor

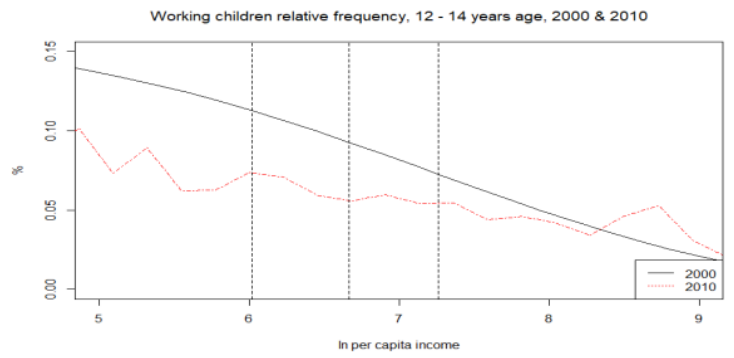

Panel B. 12 and 14 year old boys in urban areas.

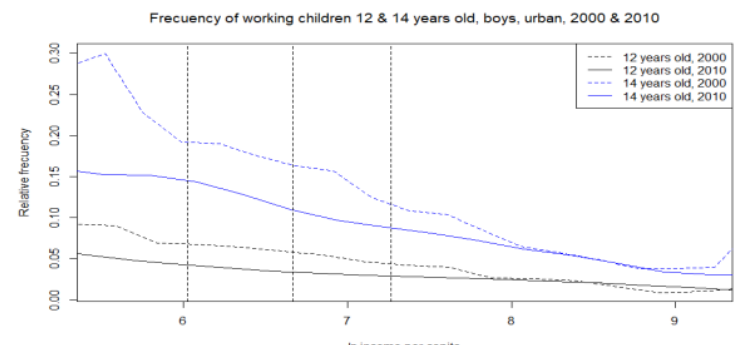

Panel C. 12 and 14 year old boys in rural areas.

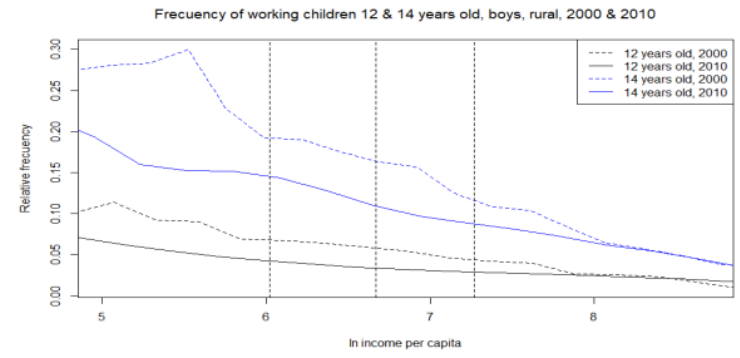

Panel D. 12 and 14 year old girls in urban areas.

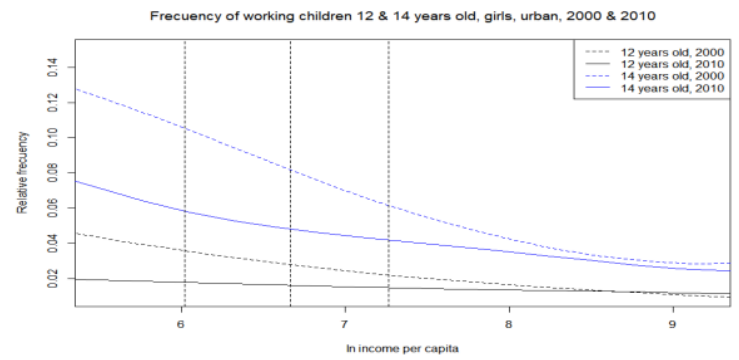

Panel E. 12 and 14 year old girls in rural areas.

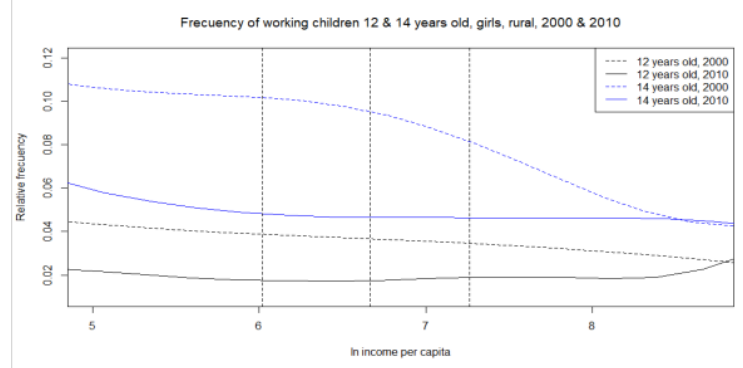

$\%$ Attend School
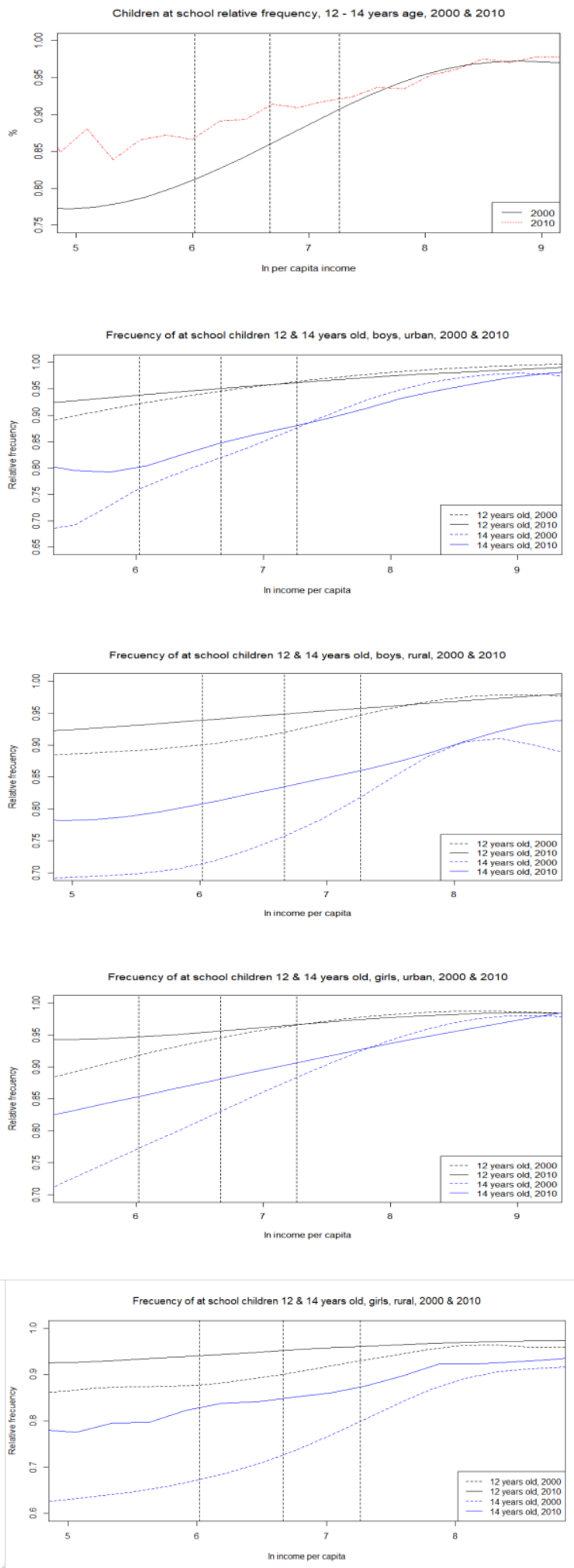
Table 1. Mean values for characteristics of the population aged 12 to 14.

Panel A. By whether the child works and/or attends school.

\begin{tabular}{|c|c|c|c|c|c|c|c|c|}
\hline \multirow[b]{2}{*}{ Year } & \multicolumn{2}{|c|}{ Child works } & \multicolumn{2}{|c|}{$\begin{array}{l}\text { Child does not } \\
\text { work }\end{array}$} & \multicolumn{2}{|c|}{$\begin{array}{l}\text { Child attends } \\
\text { school }\end{array}$} & \multicolumn{2}{|c|}{$\begin{array}{l}\text { Child does not } \\
\text { attend school }\end{array}$} \\
\hline & 2000 & 2010 & 2000 & 2010 & 2000 & 2010 & 2000 & 2010 \\
\hline School attendance & 0.49 & 0.54 & 0.91 & 0.94 & & & & \\
\hline Child labor & & & & & 0.05 & 0.03 & 0.35 & 0.27 \\
\hline Edu. head & 4.49 & 6.23 & 6.92 & 8.49 & 7.14 & 8.63 & 3.73 & 5.59 \\
\hline Log PCI & 6.42 & 6.85 & 6.79 & 7.09 & 6.82 & 7.10 & 6.29 & 6.76 \\
\hline Govt. help & 0.20 & 0.41 & 0.14 & 0.36 & 0.13 & 0.36 & 0.20 & 0.38 \\
\hline Remittances & 0.05 & 0.07 & 0.03 & 0.07 & 0.03 & 0.07 & 0.05 & 0.07 \\
\hline Social Health Insurance & 0.38 & 0.64 & 0.54 & 0.72 & 0.55 & 0.73 & 0.34 & 0.60 \\
\hline Age & 13.30 & 13.29 & 12.96 & 12.99 & 12.94 & 12.98 & 13.33 & 13.30 \\
\hline Household size & 6.27 & 5.54 & 5.69 & 5.12 & 5.63 & 5.09 & 6.52 & 5.68 \\
\hline$\%$ Children & 48.47 & 44.57 & 45.26 & 42.92 & 45.21 & 42.95 & 47.86 & 43.64 \\
\hline
\end{tabular}

Panel B. By urban or rural sector.

\begin{tabular}{|c|c|c|c|c|c|c|}
\hline \multirow[b]{2}{*}{ Year } & \multicolumn{3}{|c|}{ Urban } & \multicolumn{3}{|c|}{ Rural } \\
\hline & 2000 & 2010 & Change $(\%)$ & 2000 & 2010 & Change (\%) \\
\hline Child Labor & 0.06 & 0.04 & -41 & 0.11 & 0.06 & -43 \\
\hline School Attendance & 0.92 & 0.94 & 2 & 0.82 & 0.89 & 9 \\
\hline Edu. head & 8.05 & 9.59 & 19 & 4.65 & 6.39 & 37 \\
\hline Log PCI & 7.10 & 7.34 & 3 & 6.24 & 6.64 & 6 \\
\hline Govt. help & 0.01 & 0.22 & 2,290 & 0.34 & 0.61 & 77 \\
\hline Remittances & 0.03 & 0.06 & 122 & 0.05 & 0.07 & 52 \\
\hline Social Health Insurance & 0.64 & 0.73 & 14 & 0.33 & 0.69 & 108 \\
\hline Age & 12.99 & 13.00 & 0 & 12.98 & 13.00 & 0 \\
\hline Household size & 5.39 & 4.89 & -9 & 6.28 & 5.55 & -12 \\
\hline$\%$ Children & 44.14 & 42.44 & -4 & 47.68 & 43.93 & -8 \\
\hline
\end{tabular}


Table 2. Decomposition of the difference in child labor and school attendance between 2000 and 2010, by sex and size of locality.

\begin{tabular}{|c|c|c|c|c|c|c|c|c|}
\hline & \multicolumn{4}{|c|}{ Panel A. Child Labor } & \multicolumn{4}{|c|}{ Panel B. School Attendance } \\
\hline & Boys-Urban & Boys-Rural & Girls-Urban & Girls-Rural & Boys-Urban & Boys-Rural & Girls-Urban & Girls-Rural \\
\hline Pr 2000 & 0.083 & 0.156 & 0.043 & 0.064 & 0.916 & 0.839 & 0.918 & 0.804 \\
\hline $\operatorname{Pr} 2010$ & 0.050 & 0.088 & 0.024 & 0.039 & 0.932 & 0.894 & 0.944 & 0.892 \\
\hline Difference & 0.033 & 0.068 & 0.019 & 0.026 & -0.015 & -0.055 & -0.026 & -0.088 \\
\hline Explained & 0.019 & 0.043 & 0.009 & 0.020 & -0.028 & -0.064 & -0.029 & -0.080 \\
\hline \multirow[t]{3}{*}{ Edu. head } & $0.0129 * * *$ & $0.0183 * * *$ & $0.0056 * * *$ & $0.0059 * * *$ & $-0.0168 * * *$ & $-0.0272 * * *$ & $-0.0166^{* * *}$ & $-0.0277 * * *$ \\
\hline & $(0.0009)$ & $(0.0001)$ & $(0.0001)$ & $(0.0001)$ & $(0.0001)$ & $(0.0001)$ & $(0.0001)$ & $(0.0001)$ \\
\hline & $66.58 \%$ & $42.68 \%$ & $62.58 \%$ & $29.37 \%$ & $60.44 \%$ & $42.21 \%$ & $57.17 \%$ & $34.47 \%$ \\
\hline \multirow[t]{3}{*}{ Log PCI } & $0.0009 * * *$ & $0.0008^{* * *}$ & $0.0001 * *$ & $-0.0019 * * *$ & $-0.0039 * * *$ & $-0.0035 * * *$ & $-0.0034 * * *$ & $-0.0028 * * *$ \\
\hline & $(0.0025)$ & $(0.0001)$ & $(0.0001)$ & $(0.0001)$ & $(0.0001)$ & $(0.0001)$ & $(0.0001)$ & $(0.0001)$ \\
\hline & $4.55 \%$ & $1.85 \%$ & $1.22 \%$ & $-9.31 \%$ & $13.95 \%$ & $5.40 \%$ & $11.80 \%$ & $3.49 \%$ \\
\hline \multirow[t]{3}{*}{ Govt. help } & $0.0025 * * *$ & $0.0069 * * *$ & $0.0016 * * *$ & $0.0058 * * *$ & $-0.0031 * * *$ & $-0.0144 * * *$ & $-0.0050 * * *$ & $-0.0186 * * *$ \\
\hline & $(0.0001)$ & $(0.0001)$ & $(0.0001)$ & $(0.0001)$ & $(0.0001)$ & $(0.0001)$ & $(0.0001)$ & $(0.0002)$ \\
\hline & $13.09 \%$ & $16.02 \%$ & $17.45 \%$ & $28.73 \%$ & $11.33 \%$ & $22.37 \%$ & $17.28 \%$ & $23.16 \%$ \\
\hline \multirow[t]{3}{*}{ Remittances } & $-0.0003 * * *$ & $-0.0003 * * *$ & $-0.0001 * * *$ & $0.0000 * * *$ & $0.0002 * * *$ & $-0.0002 * * *$ & $0.0000 * * *$ & $-0.0004 * * *$ \\
\hline & $(0.0000)$ & $(0.0000)$ & $(0.0000)$ & $(0.0000)$ & $(0.0000)$ & $(0.0000)$ & $(0.0000)$ & $(0.0000)$ \\
\hline & $-1.37 \%$ & $-0.67 \%$ & $-1.25 \%$ & $0.24 \%$ & $-0.64 \%$ & $0.25 \%$ & $0.14 \%$ & $0.44 \%$ \\
\hline \multirow[t]{3}{*}{ Social Health Insurance } & $0.0026 * * *$ & $0.0095 * * *$ & $0.0009 * * *$ & $0.0069 * * *$ & $-0.0031 * * *$ & $-0.0122 * * *$ & $-0.0025 * * *$ & $-0.0219 * * *$ \\
\hline & $(0.0000)$ & $(0.0002)$ & $(0.0000)$ & $(0.0001)$ & $(0.0000)$ & $(0.0002)$ & $(0.0000)$ & $(0.0002)$ \\
\hline & $13.33 \%$ & $22.18 \%$ & $10.21 \%$ & $34.37 \%$ & $11.08 \%$ & $18.87 \%$ & $8.70 \%$ & $27.20 \%$ \\
\hline \multirow[t]{3}{*}{ Demog } & $0.0021 * * *$ & $0.0067 * * *$ & $0.0016^{* * *}$ & $0.0031 * * *$ & $-0.0025 * * *$ & $-0.0065 * * *$ & $-0.0032 * * *$ & $-0.0099 * * *$ \\
\hline & $(0.0001)$ & $(0.0001)$ & $(0.0001)$ & $(0.0001)$ & $(0.0001)$ & $(0.0001)$ & $(0.0001)$ & $(0.0001)$ \\
\hline & $10.72 \%$ & $15.64 \%$ & $17.28 \%$ & $15.50 \%$ & $9.18 \%$ & $10.16 \%$ & $11.06 \%$ & $12.37 \%$ \\
\hline \multirow[t]{3}{*}{ State } & $-0.0013 * * *$ & $0.0010^{* * *}$ & $-0.0007 * * *$ & $0.0002 * * *$ & $0.0015^{* * *}$ & $-0.0005 * * *$ & $0.0018^{* * * *}$ & $0.0009 * * *$ \\
\hline & $(0.0000)$ & $(0.0000)$ & $(0.0000)$ & $(0.0000)$ & $(0.0000)$ & $(0.0000)$ & $(0.0000)$ & $(0.0000)$ \\
\hline & $-6.96 \%$ & $2.30 \%$ & $-7.48 \%$ & $1.10 \%$ & $-5.38 \%$ & $0.72 \%$ & $-6.18 \%$ & $-1.14 \%$ \\
\hline
\end{tabular}


Table 3. Decomposition of the difference in child labor and school attendance between 2000 and 2010, by age and sex.

\begin{tabular}{|c|c|c|c|c|c|c|}
\hline \multirow[b]{2}{*}{ Age } & \multicolumn{3}{|l|}{ Boys } & \multicolumn{3}{|l|}{ Girls } \\
\hline & 12 & 13 & 14 & 12 & 13 & 14 \\
\hline \multicolumn{7}{|l|}{ Panel A. Child Labor } \\
\hline Pr 2000 & 0.0648 & 0.1024 & 0.1710 & 0.0283 & 0.0484 & 0.0770 \\
\hline Pr 2010 & 0.0341 & 0.0598 & 0.0984 & 0.0251 & 0.0218 & 0.0405 \\
\hline Difference & 0.0306 & 0.0426 & 0.0727 & 0.0032 & 0.0266 & 0.0365 \\
\hline Explained & 0.0161 & 0.0286 & 0.0487 & 0.0074 & 0.0133 & 0.0201 \\
\hline \multirow[t]{3}{*}{ Edu. head } & $0.0081 * * *$ & $0.0152 * * *$ & $0.0237 * * *$ & $0.0036 * * *$ & $0.0061 * * *$ & $0.0097 * * *$ \\
\hline & $(0.0001)$ & $(0.0001)$ & $(0.0001)$ & $(0.0001)$ & $(0.0001)$ & $(0.0001)$ \\
\hline & $50.71 \%$ & $53.33 \%$ & $48.68 \%$ & $49.01 \%$ & $45.62 \%$ & $48.41 \%$ \\
\hline \multirow[t]{3}{*}{ Log PCI } & $0.0008 * * *$ & $0.0012 * * *$ & $0.0019 * * *$ & $-0.0015 * * *$ & 0.0001 & $-0.0003 * * *$ \\
\hline & $(0.0001)$ & $(0.0001)$ & $(0.0001)$ & $(0.0001)$ & $(0.0001)$ & $(0.0001)$ \\
\hline & $5.27 \%$ & $4.15 \%$ & $3.83 \%$ & $-20.86 \%$ & $0.80 \%$ & $-1.42 \%$ \\
\hline \multirow[t]{3}{*}{ Govt. help } & $0.0011 * * *$ & $0.0031 * * *$ & $0.0056^{* * *}$ & $0.0019 * * *$ & $0.0031 * * *$ & $0.0046^{* * *}$ \\
\hline & $(0.0001)$ & $(0.0001)$ & $(0.0001)$ & $(0.0001)$ & $(0.0001)$ & $(0.0001)$ \\
\hline & $6.65 \%$ & $10.79 \%$ & $11.51 \%$ & $25.25 \%$ & $23.14 \%$ & $22.76 \%$ \\
\hline \multirow[t]{3}{*}{ Remittances } & $-0.0002 * * *$ & $-0.0003 * * *$ & $-0.0004 * * *$ & $0.0001 * * *$ & $-0.0001 * * *$ & $-0.0001 * * *$ \\
\hline & $(0.0000)$ & $(0.0000)$ & $(0.0000)$ & $(0.0000)$ & $(0.0000)$ & $(0.0000)$ \\
\hline & $-0.95 \%$ & $-0.98 \%$ & $-0.77 \%$ & $0.69 \%$ & $-0.60 \%$ & $-0.60 \%$ \\
\hline \multirow[t]{3}{*}{ Social Health Insurance } & $0.0037 * * *$ & $0.0053 * * *$ & $0.0088^{* * *}$ & $0.0033^{* * *}$ & $0.0019 * * *$ & $0.0027 * * *$ \\
\hline & $(0.0001)$ & $(0.0001)$ & $(0.0001)$ & $(0.0001)$ & $(0.0001)$ & $(0.0001)$ \\
\hline & $23.22 \%$ & $18.47 \%$ & $18.16 \%$ & $45.35 \%$ & $13.98 \%$ & $13.33 \%$ \\
\hline \multirow[t]{3}{*}{ Demog } & $0.0025^{* * *}$ & $0.0051 * * *$ & $0.0096^{* * *}$ & $0.0009 * * *$ & $0.0025 * * *$ & $0.0039 * * *$ \\
\hline & $(0.0001)$ & $(0.0001)$ & $(0.0001)$ & $(0.0001)$ & $(0.0001)$ & $(0.0001)$ \\
\hline & $15.46 \%$ & $17.95 \%$ & $19.63 \%$ & $12.83 \%$ & $18.50 \%$ & $19.35 \%$ \\
\hline \multirow[t]{3}{*}{ State } & -0.0001 & $-0.0011 * * *$ & $-0.0005 * * *$ & $-0.0009 * * *$ & $-0.0002 * * *$ & $-0.0004 * * *$ \\
\hline & $(0.0000)$ & $(0.0000)$ & $(0.0000)$ & $(0.0000)$ & $(0.0000)$ & $(0.0000)$ \\
\hline & $-0.34 \%$ & $-3.72 \%$ & $-1.04 \%$ & $-12.24 \%$ & $-1.47 \%$ & $-1.85 \%$ \\
\hline \multicolumn{7}{|c|}{ Panel B. School Attendance } \\
\hline $\operatorname{Pr} 2000$ & 0.9417 & 0.8940 & 0.8185 & 0.9334 & 0.8767 & 0.8091 \\
\hline Pr 2010 & 0.9568 & 0.9203 & 0.8763 & 0.9531 & 0.9275 & 0.8922 \\
\hline Difference & -0.0151 & -0.0263 & -0.0579 & -0.0197 & -0.0508 & -0.0831 \\
\hline Explained & -0.0251 & -0.0437 & -0.0675 & -0.0273 & -0.0501 & -0.0708 \\
\hline \multirow[t]{3}{*}{ Edu. head } & $-0.0112 * * *$ & $-0.0206 * * *$ & $-0.0345 * * *$ & $-0.0134 * * *$ & $-0.0221 * * *$ & $-0.0319 * * *$ \\
\hline & $(0.0001)$ & $(0.0001)$ & $(0.0001)$ & $(0.0001)$ & $(0.0001)$ & $(0.0001)$ \\
\hline & $44.54 \%$ & $47.21 \%$ & $51.16 \%$ & $49.04 \%$ & $44.04 \%$ & $45.10 \%$ \\
\hline Log PCI & $-0.0024 * * *$ & $-0.0046 * * *$ & $-0.0061 * * *$ & $-0.0010 * * *$ & $-0.0052 * * *$ & $-0.0074 * * *$ \\
\hline
\end{tabular}




\begin{tabular}{|c|c|c|c|c|c|c|}
\hline & $(0.0001)$ & $(0.0001)$ & $(0.0001)$ & $(0.0001)$ & $(0.0001)$ & $(0.0001)$ \\
\hline & $9.51 \%$ & $10.52 \%$ & $9.09 \%$ & $3.84 \%$ & $10.30 \%$ & $10.48 \%$ \\
\hline \multirow[t]{3}{*}{ Govt. help } & $-0.0048 * * *$ & $-0.0066 * * *$ & $-0.0088 * * *$ & $-0.0044 * * *$ & $-0.0083 * * *$ & $-0.0108 * * *$ \\
\hline & $(0.0001)$ & $(0.0001)$ & $(0.0001)$ & $(0.0001)$ & $(0.0001)$ & $(0.0002)$ \\
\hline & $19.10 \%$ & $15.16 \%$ & $12.98 \%$ & $15.91 \%$ & $16.53 \%$ & $15.32 \%$ \\
\hline \multirow[t]{3}{*}{ Remittances } & 0.0000 & 0.0000 & 0.0000 & $-0.0002 * * *$ & $-0.0001 * * *$ & $-0.0001 * * *$ \\
\hline & $(0.0000)$ & $(0.0000)$ & $(0.0000)$ & $(0.0000)$ & $(0.0000)$ & $(0.0000)$ \\
\hline & $0.15 \%$ & $-0.11 \%$ & $-0.03 \%$ & $0.77 \%$ & $0.17 \%$ & $0.13 \%$ \\
\hline \multirow[t]{3}{*}{ Social Health Insurance } & $-0.0043 * * *$ & $-0.0073 * * *$ & $-0.0102 * * *$ & $-0.0076^{* * *}$ & $-0.0086^{* * *}$ & $-0.0119 * * *$ \\
\hline & $(0.0001)$ & $(0.0001)$ & $(0.0001)$ & $(0.0001)$ & $(0.0001)$ & $(0.0001)$ \\
\hline & $16.98 \%$ & $16.80 \%$ & $15.03 \%$ & $27.72 \%$ & $17.17 \%$ & $16.74 \%$ \\
\hline \multirow[t]{3}{*}{ Demog } & $-0.0030 * * *$ & $-0.0057 * * *$ & $-0.0093 * * *$ & $-0.0033 * * *$ & $-0.0074 * * *$ & $-0.0106^{* * *}$ \\
\hline & $(0.0001)$ & $(0.0001)$ & $(0.0001)$ & $(0.0001)$ & $(0.0001)$ & $(0.0001)$ \\
\hline & $11.81 \%$ & $13.12 \%$ & $13.83 \%$ & $12.24 \%$ & $14.72 \%$ & $14.92 \%$ \\
\hline \multirow[t]{3}{*}{ State } & $0.0005 * * *$ & $0.0012 * * *$ & $0.0014 * * *$ & $0.0026 * * *$ & $0.0015 * * *$ & $0.0019 * * *$ \\
\hline & $(0.0000)$ & $(0.0001)$ & $(0.0001)$ & $(0.0001)$ & $(0.0001)$ & $(0.0001)$ \\
\hline & $-2.12 \%$ & $-2.68 \%$ & $-2.06 \%$ & $-9.47 \%$ & $-2.93 \%$ & $-2.74 \%$ \\
\hline
\end{tabular}

The variable "Demog" includes age, size of the household, percent of children and size of the locality. 
Table 4. Grouping of states by poverty levels

\begin{tabular}{|l|l|l|}
\hline $\begin{array}{l}\text { Percentage of the } \\
\text { population in poverty }\end{array}$ & Group & States \\
\hline $6 \%-9 \%$ & 1 & Baja California, México City, Nuevo León \\
\hline $10 \%-14 \%$ & 2 & $\begin{array}{l}\text { Aguascalientes, Baja California Sur, Chihuahua, Coahuila, Colima, } \\
\text { Jalisco, Sonora, Tamaulipas. }\end{array}$ \\
\hline $16 \%-22 \%:$ & 3 & $\begin{array}{l}\text { Durango, Guanajuato, México, Morelos, Nayarit, Querétaro, } \\
\text { Quintana Roo, Sinaloa }\end{array}$ \\
\hline $26 \%-34 \%:$ & 4 & $\begin{array}{l}\text { Campeche, Hidalgo, Michoacán, Puebla, San Luis Potosí, Tabasco, } \\
\text { Tlaxcala, Veracruz, Yucatán, Zacatecas }\end{array}$ \\
\hline $44-52 \%$ & 5 & \begin{tabular}{l} 
Chiapas, Guerrero, Oaxaca. \\
\hline
\end{tabular}
\end{tabular}

Group 1: 3 states, Group 2: 8 states, Group 3: 8 states, Group 4: 10 states, Group 5: 3 states. 
Table 5. Mean values 2000 and 2010, by state poverty groups

\begin{tabular}{|c|c|c|c|c|c|c|c|c|c|c|}
\hline \multirow{3}{*}{$\begin{array}{l}\text { Group } \\
\text { Year }\end{array}$} & \multicolumn{4}{|c|}{ Low Poverty } & & & \multicolumn{4}{|c|}{ High Poverty } \\
\hline & \multicolumn{2}{|c|}{1} & \multicolumn{2}{|c|}{2} & \multicolumn{2}{|c|}{3} & \multicolumn{2}{|c|}{4} & \multicolumn{2}{|c|}{5} \\
\hline & 2000 & 2010 & 2000 & 2010 & 2000 & 2010 & 2000 & 2010 & 2000 & 2010 \\
\hline Child Labor & 0.04 & 0.03 & 0.08 & 0.05 & 0.08 & 0.04 & 0.10 & 0.06 & 0.11 & 0.06 \\
\hline School Attendance & 0.94 & $0.94 *$ & 0.88 & 0.92 & 0.88 & 0.93 & 0.85 & 0.91 & 0.84 & 0.90 \\
\hline Edu. head & 8.64 & 9.96 & 7.28 & 9.00 & 6.80 & 8.52 & 5.73 & 7.62 & 5.30 & 6.75 \\
\hline Log PCI & 7.30 & 7.47 & 7.06 & 7.29 & 6.81 & 7.14 & 6.41 & 6.85 & 6.17 & 6.54 \\
\hline Govt. help & 0.01 & 0.21 & 0.07 & 0.27 & 0.11 & 0.32 & 0.24 & 0.47 & 0.31 & 0.58 \\
\hline Remittances & 0.02 & 0.07 & 0.04 & 0.07 & 0.04 & 0.07 & 0.04 & 0.06 & 0.03 & 0.06 \\
\hline $\begin{array}{l}\text { Social Health } \\
\text { Insurance }\end{array}$ & 0.67 & 0.76 & 0.66 & 0.78 & 0.54 & 0.72 & 0.40 & 0.68 & 0.31 & 0.61 \\
\hline Age & 12.99 & 12.99 & 12.99 & $13.00 *$ & 12.99 & 13.00 & 12.98 & 13.01 & 12.98 & 13.01 \\
\hline Household size & 5.19 & 4.78 & 5.60 & 5.07 & 5.77 & 5.14 & 5.96 & 5.24 & 6.11 & 5.48 \\
\hline$\%$ Children & 43.08 & 41.81 & 45.20 & 43.34 & 45.42 & 42.90 & 46.44 & 43.07 & 47.60 & 43.98 \\
\hline
\end{tabular}


Table 6. Decomposition of the difference in child labor and school attendance between 2000 and 2010 , by state poverty level.

\begin{tabular}{|c|c|c|c|c|c|c|c|c|c|c|}
\hline \multirow[b]{2}{*}{ Group } & \multicolumn{4}{|l|}{ Low Poverty } & \multirow{2}{*}{$\begin{array}{l}\text { High Poverty } \\
5\end{array}$} & \multicolumn{2}{|c|}{ Low Poverty } & \multirow[b]{2}{*}{3} & \multirow{2}{*}{\multicolumn{2}{|c|}{$\begin{array}{l}\text { High Poverty } \\
5\end{array}$}} \\
\hline & 1 & 2 & 3 & 4 & & 1 & 2 & & & \\
\hline \multicolumn{6}{|c|}{ Panel A. Child Labor } & \multicolumn{5}{|c|}{ Panel B. School Attendance } \\
\hline $\operatorname{Pr} 2000$ & 0.0415 & 0.0813 & 0.0767 & 0.0987 & 0.1087 & 0.9409 & 0.8779 & 0.8850 & 0.8566 & 0.8415 \\
\hline Pr 2010 & 0.0251 & 0.0509 & 0.0401 & 0.0555 & 0.0646 & 0.9427 & 0.9165 & 0.9297 & 0.9127 & 0.8979 \\
\hline Difference & 0.0164 & 0.0305 & 0.0365 & 0.0432 & 0.0441 & -0.0018 & -0.0386 & -0.0447 & -0.0560 & -0.0564 \\
\hline Explained & 0.0085 & 0.0242 & 0.0199 & 0.0305 & 0.0310 & -0.0176 & -0.0510 & -0.0449 & -0.0634 & -0.0631 \\
\hline \multirow[t]{2}{*}{ Edu. Head } & $\begin{array}{l}0.0051 * * * \\
(0.0001)\end{array}$ & $\begin{array}{l}0.0121 * * * \\
(0.0001)\end{array}$ & $\begin{array}{l}0.0117 * * * \\
(0.0001)\end{array}$ & $\begin{array}{l}0.0152 * * * \\
(0.0001)\end{array}$ & $\begin{array}{l}0.0109 * * * \\
(0.0001)\end{array}$ & $\begin{array}{l}-0.0120 * * * \\
(0.0001)\end{array}$ & $\begin{array}{l}-0.0253 * * * \\
(0.0001)\end{array}$ & $\begin{array}{l}-0.0221 * * * \\
(0.0001)\end{array}$ & $\begin{array}{l}-0.0279 * * * \\
(0.0001)\end{array}$ & $\begin{array}{l}-0.0218^{* * * *} \\
(0.0002)\end{array}$ \\
\hline & $60.10 \%$ & $49.76 \%$ & $58.67 \%$ & $49.93 \%$ & $35.09 \%$ & $68.14 \%$ & $49.68 \%$ & $49.27 \%$ & $43.94 \%$ & $34.53 \%$ \\
\hline \multirow[t]{2}{*}{ Log PCI } & $\begin{array}{l}0.0000 \\
(0.0001)\end{array}$ & $\begin{array}{l}-0.0027 * * * \\
(0.0001)\end{array}$ & $\begin{array}{l}-0.0004 * * * \\
(0.0001)\end{array}$ & $\begin{array}{l}0.0000 \\
(0.0001)\end{array}$ & $\begin{array}{l}0.0035 * * * \\
(0.0001)\end{array}$ & $\begin{array}{l}-0.0014 * * * \\
(0.0001)\end{array}$ & $\begin{array}{l}-0.0023 * * * \\
(0.0001)\end{array}$ & $\begin{array}{l}-0.0049 * * * \\
(0.0001)\end{array}$ & $\begin{array}{l}-0.0033 * * * \\
(0.0001)\end{array}$ & $\begin{array}{l}-0.0040 * * * \\
(0.0000)\end{array}$ \\
\hline & $0.14 \%$ & $-11.17 \%$ & $-1.97 \%$ & $-0.06 \%$ & $11.17 \%$ & $7.71 \%$ & $4.49 \%$ & $10.91 \%$ & $5.13 \%$ & $6.39 \%$ \\
\hline \multirow[t]{3}{*}{ Gov. help } & $0.0015^{* * *}$ & $0.0039 * * *$ & $0.0036^{* * *}$ & $0.0049 * * *$ & $0.0053^{* * *} *$ & $-0.0022 * * *$ & $-0.0082 * * *$ & $-0.0075 * * *$ & $-0.0118 * * *$ & $-0.0149 * * *$ \\
\hline & $(0.0001)$ & $(0.0001)$ & $(0.0001)$ & $(0.0001)$ & $(0.0002)$ & $(0.0001)$ & $(0.0001)$ & $(0.0001)$ & $(0.0001)$ & $(0.0002)$ \\
\hline & $18.16 \%$ & $16.19 \%$ & $18.26 \%$ & $16.12 \%$ & $17.22 \%$ & $12.65 \%$ & $16.07 \%$ & $16.72 \%$ & $18.58 \%$ & $23.53 \%$ \\
\hline \multirow[t]{3}{*}{ Remittances } & $-0.0005^{* * *}$ & $-0.0001 * * *$ & $-0.0002 * * *$ & $-0.0003 * * *$ & $-0.0002 * * *$ & $0.0011^{* * *}$ & $-0.0001 * * *$ & $0.0001 * * *$ & 0.0000 & $-0.0004 * * *$ \\
\hline & $(0.0001)$ & $(0.0000)$ & $(0.0000)$ & $(0.0000)$ & $(0.0000)$ & $(0.0001)$ & $(0.0000)$ & $(0.0000)$ & $(0.0000)$ & $(0.0000)$ \\
\hline & $-6.16 \%$ & $-0.39 \%$ & $-1.16 \%$ & $-0.82 \%$ & $-0.49 \%$ & $-6.10 \%$ & $0.29 \%$ & $-0.25 \%$ & $-0.01 \%$ & $0.57 \%$ \\
\hline \multirow[t]{3}{*}{$\begin{array}{l}\text { Social Health } \\
\text { Insurance }\end{array}$} & $0.0010^{* * *}$ & $0.0049 * * *$ & $0.0020 * * *$ & $0.0070^{* * *}$ & $0.0088^{* * *}$ & $-0.0016 * * *$ & $-0.0066 * * *$ & $-0.0055^{* * *}$ & $-0.0128 * * *$ & $-0.0161 * * *$ \\
\hline & $(0.0000)$ & $(0.0001)$ & $(0.0001)$ & $(0.0001)$ & $(0.0002)$ & $(0.0001)$ & $(0.0001)$ & $(0.0001)$ & $(0.0001)$ & $(0.0003)$ \\
\hline & $11.98 \%$ & $20.39 \%$ & $10.25 \%$ & $22.97 \%$ & $28.33 \%$ & $9.10 \%$ & $13.03 \%$ & $12.25 \%$ & $20.14 \%$ & $25.46 \%$ \\
\hline \multirow[t]{3}{*}{ Demog } & $0.0013^{* * *}$ & $0.0061^{* * *}$ & $0.0032 * * *$ & $0.0036^{* * *}$ & $0.0027 * * *$ & $-0.0015^{* * *}$ & $-0.0084 * * *$ & $-0.0050 * * *$ & $-0.0078 * * *$ & $-0.0060 * * *$ \\
\hline & $(0.0001)$ & $(0.0001)$ & $(0.0001)$ & $(0.0001)$ & $(0.0002)$ & $(0.0001)$ & $(0.0001)$ & $(0.0001)$ & $(0.0001)$ & $(0.0002)$ \\
\hline & $15.64 \%$ & $25.21 \%$ & $15.93 \%$ & $11.86 \%$ & $8.71 \%$ & $8.37 \%$ & $16.52 \%$ & $11.14 \%$ & $12.23 \%$ & $9.50 \%$ \\
\hline
\end{tabular}

The variable "Demog" includes age, size of the household, percent of children and size of the locality 
Table 7. Fraction of households with Seguro Social (formal sector), Seguro Popular (informal sector), and no insurance.

\begin{tabular}{|c|c|c|c|c|c|c|c|c|c|c|}
\hline \multicolumn{7}{|c|}{ Low Poverty } & \multicolumn{4}{|c|}{ High Poverty } \\
\hline \multirow{2}{*}{$\begin{array}{l}\text { Group } \\
\text { Year }\end{array}$} & \multicolumn{2}{|c|}{1} & \multicolumn{2}{|c|}{2} & \multicolumn{2}{|c|}{3} & \multicolumn{2}{|c|}{4} & \multicolumn{2}{|c|}{5} \\
\hline & 2000 & 2010 & 2000 & 2010 & 2000 & 2010 & 2000 & 2010 & 2000 & 2010 \\
\hline Seguro Social & 0.67 & 0.63 & 0.66 & 0.60 & 0.54 & 0.47 & 0.40 & 0.36 & 0.31 & 0.26 \\
\hline Seguro Popular & 0 & 0.13 & 0 & 0.18 & 0 & 0.25 & 0 & 0.32 & 0 & 0.35 \\
\hline No Insurance & 0.33 & 0.24 & 0.34 & 0.22 & 0.46 & 0.28 & 0.60 & 0.32 & 0.69 & 0.39 \\
\hline
\end{tabular}


Table 8. Decomposition of the difference in child labor and school attendance between 2000 and 2010, by type of access to social health insurance.

\begin{tabular}{|c|c|c|c|c|c|c|c|c|c|c|}
\hline \multicolumn{4}{|c|}{ Low Poverty } & \multicolumn{2}{|c|}{ High Poverty } & \multicolumn{3}{|c|}{ Low Poverty } & \multicolumn{2}{|c|}{ High Poverty } \\
\hline Group & 1 & 2 & 3 & 4 & 5 & 1 & 2 & 3 & 4 & 5 \\
\hline \multicolumn{6}{|c|}{ Panel A. Child Labor } & \multicolumn{5}{|c|}{ Panel B. School Attendance } \\
\hline $\operatorname{Pr} 2000$ & 0.0415 & 0.0813 & 0.0767 & 0.0987 & 0.1087 & 0.9409 & 0.8779 & 0.8850 & 0.8566 & 0.8415 \\
\hline Pr 2010 & 0.0251 & 0.0509 & 0.0401 & 0.0555 & 0.0646 & 0.9427 & 0.9165 & 0.9297 & 0.9127 & 0.8979 \\
\hline Difference & 0.0164 & 0.0305 & 0.0365 & 0.0432 & 0.0441 & -0.0018 & -0.0386 & -0.0447 & -0.0560 & -0.0564 \\
\hline Explained & 0.0083 & 0.0231 & 0.0189 & 0.0283 & 0.0295 & -0.0162 & -0.0484 & -0.0427 & -0.0577 & -0.0566 \\
\hline \multirow[t]{2}{*}{ Edu. Head } & $\begin{array}{l}0.0051 * * * \\
(0.0000)\end{array}$ & $\begin{array}{l}0.0119 * * * \\
(0.0001)\end{array}$ & $\begin{array}{l}0.012 * * * \\
(0.0000)\end{array}$ & $\begin{array}{l}0.0153 * * * \\
(0.0001)\end{array}$ & $\begin{array}{l}0.0106 * * * \\
(0.0001)\end{array}$ & $\begin{array}{l}-0.0116^{* * *} \\
(0.0001)\end{array}$ & $\begin{array}{l}-0.0253 * * * \\
(0.0001)\end{array}$ & $\begin{array}{l}-0.0211 * * * \\
(0.0001)\end{array}$ & $\begin{array}{l}-0.027 * * * \\
(0.0001)\end{array}$ & $\begin{array}{l}-0.0204 * * * \\
(0.0001)\end{array}$ \\
\hline & $61.20 \%$ & $51.60 \%$ & $63.60 \%$ & $53.97 \%$ & $35.97 \%$ & $71.27 \%$ & $52.32 \%$ & $49.49 \%$ & $46.84 \%$ & $36.09 \%$ \\
\hline \multirow[t]{2}{*}{ Log PCI } & $\begin{array}{l}0.0000 \\
(0.0000)\end{array}$ & $\begin{array}{l}-0.0027 * * * \\
(0.0000)\end{array}$ & $\begin{array}{l}-0.0004 * * * \\
(0.0000)\end{array}$ & $\begin{array}{l}-0.0002 \\
(0.0001)\end{array}$ & $\begin{array}{l}0.0034 * * * \\
(0.0001)\end{array}$ & $\begin{array}{l}-0.0013 * * * \\
(0.0000)\end{array}$ & $\begin{array}{l}-0.0021 * * * \\
(0.0001)\end{array}$ & $\begin{array}{l}-0.0047 * * * \\
(0.0000)\end{array}$ & $\begin{array}{l}-0.0029 * * * \\
(0.0001)\end{array}$ & $\begin{array}{l}-0.0036 * * * \\
(0.0001)\end{array}$ \\
\hline & $0.02 \%$ & $-11.69 \%$ & $-2.37 \%$ & $-0.56 \%$ & $11.36 \%$ & $7.72 \%$ & $4.39 \%$ & $11.03 \%$ & $5.01 \%$ & $6.45 \%$ \\
\hline \multirow[t]{2}{*}{ Gov. help } & $\begin{array}{l}0.0016 * * * \\
(0.0000)\end{array}$ & $\begin{array}{l}0.0043 * * * \\
(0.0000)\end{array}$ & $\begin{array}{l}0.004 * * * \\
(0.0000)\end{array}$ & $\begin{array}{l}0.0055^{* * *} \\
(0.0000)\end{array}$ & $\begin{array}{l}0.0058 * * * \\
(0.0001)\end{array}$ & $\begin{array}{l}-0.0026^{* * *} \\
(0.0001)\end{array}$ & $\begin{array}{l}-0.0089 * * * \\
(0.0001)\end{array}$ & $\begin{array}{l}-0.0083 * * * \\
(0.0001)\end{array}$ & $\begin{array}{l}-0.0134 * * * \\
(0.0001)\end{array}$ & $\begin{array}{l}-0.017 * * * \\
(0.0002)\end{array}$ \\
\hline & $19.44 \%$ & $18.50 \%$ & $21.13 \%$ & $19.46 \%$ & $19.62 \%$ & $16.23 \%$ & $18.48 \%$ & $19.57 \%$ & $23.27 \%$ & $29.99 \%$ \\
\hline \multirow[t]{2}{*}{ Remittances } & $\begin{array}{l}-0.0005 * * * \\
(0.0000)\end{array}$ & $\begin{array}{l}-0.0001 * * * \\
(0.0000)\end{array}$ & $\begin{array}{l}-0.0002 * * * \\
(0.0000)\end{array}$ & $\begin{array}{l}-0.0002 * * * \\
(0.0000)\end{array}$ & $\begin{array}{l}-0.0001 * * * \\
(0.0000)\end{array}$ & $\begin{array}{l}0.001 * * * \\
(0.0000)\end{array}$ & $\begin{array}{l}-0.0001 * * * \\
(0.0000)\end{array}$ & $\begin{array}{l}0.0001 * * * \\
(0.0000)\end{array}$ & $\begin{array}{l}0.0000 \\
(0.0000)\end{array}$ & $\begin{array}{l}-0.0004 * * * \\
(0.0000)\end{array}$ \\
\hline & $-6.30 \%$ & $-0.42 \%$ & $-1.18 \%$ & $-0.86 \%$ & $-0.50 \%$ & $-6.41 \%$ & $0.31 \%$ & $-0.24 \%$ & $0.02 \%$ & $0.68 \%$ \\
\hline \multirow[t]{2}{*}{ Seguro Social } & $\begin{array}{l}-0.0005^{* * *} \\
(0.0000)\end{array}$ & $\begin{array}{l}-0.0018 * * * \\
(0.0000)\end{array}$ & $\begin{array}{l}-0.0007^{* * *} \\
(0.0000)\end{array}$ & $\begin{array}{l}-0.0006^{* * *} \\
(0.0000)\end{array}$ & $\begin{array}{l}-0.0006 * * * \\
(0.0000)\end{array}$ & $\begin{array}{l}0.0012 * * * \\
(0.0000)\end{array}$ & $\begin{array}{l}0.0032 * * * \\
(0.0000)\end{array}$ & $\begin{array}{l}0.0019 * * * \\
(0.0000)\end{array}$ & $\begin{array}{l}0.0016^{* * * *} \\
(0.0000)\end{array}$ & $\begin{array}{l}0.0019 * * * \\
(0.0000)\end{array}$ \\
\hline & $-6.38 \%$ & $-7.90 \%$ & $-3.66 \%$ & $-2.08 \%$ & $-2.06 \%$ & $-7.46 \%$ & $-6.63 \%$ & $-4.48 \%$ & $-2.72 \%$ & $-3.40 \%$ \\
\hline \multirow[t]{2}{*}{ Seguro Popular } & $\begin{array}{l}0.0013 * * * \\
(0.0001)\end{array}$ & $\begin{array}{l}0.0053 * * * \\
(0.0001)\end{array}$ & $\begin{array}{l}0.0015 * * * \\
(0.0001)\end{array}$ & $\begin{array}{l}0.0053 * * * \\
(0.0001)\end{array}$ & $\begin{array}{l}0.0079 * * * \\
(0.0002)\end{array}$ & $\begin{array}{l}-0.0011^{* * * *} \\
(0.0001)\end{array}$ & $\begin{array}{l}-0.0067 * * * \\
(0.0001)\end{array}$ & $\begin{array}{l}-0.0046^{* * *} \\
(0.0001)\end{array}$ & $\begin{array}{l}-0.0078 * * * \\
(0.0002)\end{array}$ & $\begin{array}{l}-0.0109 * * * \\
(0.0003)\end{array}$ \\
\hline & $15.17 \%$ & $22.98 \%$ & $7.74 \%$ & $18.81 \%$ & $26.77 \%$ & $6.50 \%$ & $13.93 \%$ & $10.67 \%$ & $13.57 \%$ & $19.30 \%$ \\
\hline \multirow[t]{2}{*}{ Demog } & $\begin{array}{l}0.0014 * * * \\
(0.0000)\end{array}$ & $\begin{array}{l}0.0062 * * * \\
(0.0000)\end{array}$ & $\begin{array}{l}0.0028 * * * \\
(0.0000)\end{array}$ & $\begin{array}{l}0.0032 * * * \\
(0.0001)\end{array}$ & $\begin{array}{l}0.0026 * * * \\
(0.0001)\end{array}$ & $\begin{array}{l}-0.002 * * * \\
(0.0000)\end{array}$ & $\begin{array}{l}-0.0083 * * * \\
(0.0001)\end{array}$ & $\begin{array}{l}-0.006^{* * *} \\
(0.0000)\end{array}$ & $\begin{array}{l}-0.0081 * * * \\
(0.0001)\end{array}$ & $\begin{array}{l}-0.0062 * * * \\
(0.0001)\end{array}$ \\
\hline & $16.85 \%$ & $26.93 \%$ & $14.74 \%$ & $11.25 \%$ & $8.83 \%$ & $12.16 \%$ & $17.20 \%$ & $13.96 \%$ & $14.01 \%$ & $10.89 \%$ \\
\hline
\end{tabular}

The variable "Demog" includes age, size of the household, percent of children and size of the locality. 
Table 9. Marginal values of an increase in Seguro Social or an increase in Seguro Popular on the probability of a child working or attending school.

\begin{tabular}{llllll}
\hline & \multicolumn{3}{c}{ Low Poverty } & \multicolumn{3}{c}{ High Poverty } \\
Group & $\mathbf{1}$ & $\mathbf{2}$ & $\mathbf{3}$ & $\mathbf{4}$ & $\mathbf{5}$ \\
\cline { 2 - 6 } Child Labor & & & & \\
Seguro Social & -0.0096 & -0.0326 & -0.0098 & -0.025 & -0.0278 \\
& $(0.0004)$ & $(0.0004)$ & $(0.0003)$ & $(0.0004)$ & $(0.0007)$ \\
Seguro Popular & -0.0068 & -0.0211 & -0.0045 & -0.0141 & -0.0200 \\
& $(0.0006)$ & $(0.0005)$ & $(0.0004)$ & $(0.0004)$ & $(0.0008)$ \\
School Attendance & & & & \\
Seguro Social & 0.0165 & 0.0448 & 0.0249 & 0.0476 & 0.0606 \\
& $(0.0005)$ & $(0.0005)$ & $(0.0004)$ & $(0.0004)$ & $(0.0008)$ \\
Seguro Popular & 0.0053 & 0.0255 & 0.0133 & 0.0197 & 0.0266 \\
& $(0.0008)$ & $(0.0006)$ & $(0.0005)$ & $(0.0005)$ & $(0.0009)$ \\
\hline
\end{tabular}


Table 10. Decomposition of the difference in child labor and school attendance between 2000 and 2010, when omitting the education and income variables.

\section{Child Labor}

Logistic regressions

LR

Pseudo $R^{2}$

\section{Decomposition}

Pr 2000

Pr 2010

Difference

Explained

Edu. Head

$\log$ PCI

Govt. help

Remittances

Social Health Insurance

Demog

State
(1)

(2)

351726.6
0.0825

(3)

$\begin{array}{ll}351614.2 & 286373.1 \\ 0.0825 & 0.0643\end{array}$

$\begin{array}{ll}0.0816 & 0.0816 \\ 0.0470 & 0.0470 \\ 0.0346 & 0.0346 \\ 0.0219 & 0.0217 \\ & \\ 0.0113 * * * & 0.0112 * * * \\ (0.0000) & (0.0000) \\ 51.45 \% & 51.71 \%\end{array}$

$0.0005 * * *$

(0.0000)

$2.10 \%$

$0.0033 * * *$

(0.0000)

$15.01 \%$

$-0.0001 * * *$

(0.0000)

$-0.68 \%$

$0.0045 * * *$

(0.0000)

$20.57 \%$

$0.0029 * * *$

(0.0000)

$13.38 \%$

$-0.0004 * * *$

(0.0000)

$-1.83 \%$
0.0828
0.0469
0.0359
0.0166

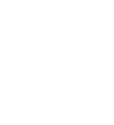

$0.0051 * * *$

(0.0000)

$30.85 \%$

$0.0032 * * *$

$0.0022 * * *$

(0.0000)

$14.77 \%$

(0.0000)

$13.02 \%$

$-0.0001 * * *$

$(0.0000)$

$-0.69 \%$

$-0.0002 * * *$

(0.0000)

$-0.0001 * * *$

$-1.39 \%$

(0.0000)

$0.0062 * * *$

$-0.69 \%$

(0.0000)

$0.0045^{* * * *}$

$37.33 \%$

(0.0000)

$0.0038 * * *$

(0.0000)

\begin{abstract}
$20.81 \%$
\end{abstract}
$22.82 \%$

$0.0032 * * *$

$-0.0004 * * *$

$(0.0000)$

(0.0000)

$14.68 \%$

$-2.63 \%$
(4)

School Attendance

(5)

(6)

$\begin{array}{lll}780123.9 & 771813.6 & 583744.5 \\ 0.1346 & 0.1332 & 0.0966\end{array}$

$\begin{array}{lll}0.8798 & 0.8798 & 0.8777 \\ 0.9209 & 0.9209 & 0.9209 \\ -0.0411 & -0.0411 & -0.0432 \\ -0.0466 & -0.0446 & -0.0346\end{array}$

$-0.0228 * * * \quad-0.0241 * * *$

$(0.0001) \quad(0.0001)$

$48.82 \% \quad 53.89 \%$

$-0.0045^{* * *}$

$-0.0128 * * *$

(0.0001)

$(0.0001)$

$9.73 \%$

$36.88 \%$

$-0.0073 * * * \quad-0.0066 * * * \quad-0.0050 * * *$

$\begin{array}{lll}(0.0000) & (0.0000) & (0.0000)\end{array}$

$15.73 \% \quad 14.77 \% \quad 14.35 \%$

$-0.0001 * * * \quad-0.0001 * * * \quad 0.0000$

$\begin{array}{lll}(0.0000) & (0.0000) & (0.0000)\end{array}$

$0.18 \% \quad 0.17 \% \quad 0.01 \%$

$-0.0086 * * * \quad-0.0092 * * * \quad-0.0120 * * *$

$\begin{array}{lll}(0.0001) & (0.0001) & (0.0001)\end{array}$

$18.54 \% \quad 20.54 \% \quad 34.62 \%$

$\begin{array}{lll}-0.0045^{* * *} & -0.0059^{* * * *} & -0.0064 * * *\end{array}$

$\begin{array}{lll}(0.0001) & (0.0000) & (0.0001)\end{array}$

$9.67 \% \quad 13.21 \% \quad 18.44 \%$

$0.0013 * * * \quad 0.0011 * * * \quad 0.0015 * * *$

$\begin{array}{lll}(0.0000) & (0.0000) \quad(0.0000)\end{array}$

$-2.68 \% \quad-2.57 \%$

$-4.27 \%$ 
Table 11. Decomposition of the difference in child labor and school attendance between 2000 and 2010, by income level of the states. Percentage of the change explained by each factor.
Low Poverty
High Poverty

Group 1

2

3

4

5

\section{Child Labor}

Log PCI

Govt. help

Remittances

Social Health

Insurance

Demog

School Attendance

29

27

28

28

22

$-1$

24

29

42

19

$-3$

23

32

14

14

$-1 \quad-1$

40

42

27

35

29

21

Govt. help

25

21

$-9$

0

17

$-1$

Social Health

Insurance

22

21

30

24

25

41

46

Demog

38

75
-1
4
5

16

21

1

42

16 